\title{
Thienopyrimidinone Based Sirtuin-2 (SIRT2)-Selective Inhibitors Bind in the Ligand Induced Selectivity Pocket
}

\author{
Sandeep Sundriyal, ${ }^{\dagger, \#}$ Sébastien Moniot, ${ }^{\S, \#}$ Zimam Mahmud, ${ }^{\ddagger}$ Shang Yao, ${ }^{\ddagger}$ Paolo Di Fruscia, ${ }^{\dagger}$ \\ Christopher R. Reynolds, " David T. Dexter, ${ }^{\perp}$ Michael J. E. Sternberg, "Eric W.-F. Lam, \\ Clemens Steegborn, ${ }^{\S}$ and Matthew J. Fuchter*, ${ }^{\dagger}$ \\ ${ }^{\dagger}$ Department of Chemistry, Imperial College London, London SW7 2AZ, U.K. \\ ${ }^{\ddagger}$ Department of Surgery \& Cancer, Imperial College London, Hammersmith Hospital Campus, Du Cane Road, London W12 0NN, U.K. \\ ${ }^{\S}$ Department of Biochemistry, University of Bayreuth, Universitaetsstrasse 30, 95447 Bayreuth, Germany \\ "Department of Life Sciences, Imperial College London, London SW7 2AZ, U.K. \\ ${ }^{\perp}$ Centre for Neuroinflammation \& Neurodegeneration, Division of Brain Sciences, Imperial College London, London W12 0NN, U.K.
}

Supporting Information

ABSTRACT: Sirtuins (SIRTs) are NAD-dependent deacylases, known to be involved in a variety of pathophysiological processes and thus remain promising therapeutic targets for further validation. Previously, we reported a novel thienopyrimidinone SIRT2 inhibitor with good potency and excellent selectivity for SIRT2. Herein, we report an extensive SAR

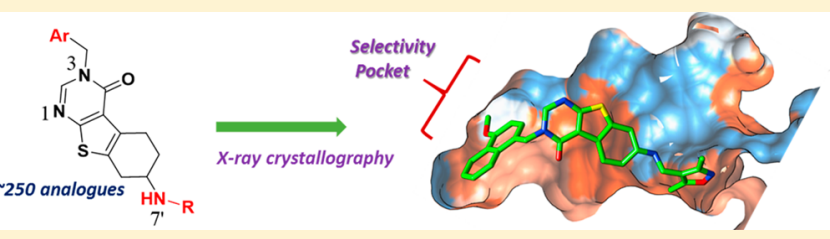
study of this chemical series and identify the key pharmacophoric elements and physiochemical properties that underpin the excellent activity observed. New analogues have been identified with submicromolar SIRT2 inhibtory activity and good to excellent SIRT2 subtype-selectivity. Importantly, we report a cocrystal structure of one of our compounds $(29 \mathrm{c})$ bound to SIRT2. This reveals our series to induce the formation of a previously reported selectivity pocket but to bind in an inverted fashion to what might be intuitively expected. We believe these findings will contribute significantly to an understanding of the mechanism of action of SIRT2 inhibitors and to the identification of refined, second generation inhibitors.

\section{INTRODUCTION}

The sirtuins (silent information regulator 2-related proteins) are enzymes that employ $\mathrm{NAD}^{+}$to mediate their deacylase activity. ${ }^{1}$ Seven sirtuin isoforms (SIRT1-7) have been identified in humans, which differ in their cellular localization, function, and specificity. ${ }^{2,3}$ Despite being labeled primarily as deacetylases, the sirtuins appear to have a broader functional enzymatic role, with recent studies reporting their ability to remove succinyl, ${ }^{4}$ malonyl, ${ }^{4}$ myristoyl, ${ }^{5}$ palmitoyl, ${ }^{6}$ and oxononanoyl groups, ${ }^{7}$ with the substrate specificity dependent on the enzyme in question. Sirtuin catalyzed deacylation occurs on histone substrates, with variable specificity, ${ }^{8-11}$ and on a large number of nonhistone proteins. ${ }^{12}$ Thus, as a consequence, the sirtuins play a significant role in various biological processes such as aging, ${ }^{13-15}$ inflammation, ${ }^{16-19}$ metabolism, ${ }^{18,20-24}$ autophagy, ${ }^{25-28}$ and DNA repair. ${ }^{22,29-31}$

Since SIRT2 regulates the cell cycle during mitosis, it is unsurprising that its deregulation has been linked to a variety of cancers. ${ }^{32-42}$ However, the role of this protein in cancer is complex and likely context specific. ${ }^{34,35,43}$ For example, while a selective SIRT2 suicide inhibitor was recently shown to result in proteolytic degradation of c-Myc, ${ }^{43}$ suggesting SIRT inhibition to be a strategy in c-Myc driven cancers, the loss of SIRT2 function has conversely recently been reported to reprogram cellular glycolytic metabolism (via PKM2 regulation), resulting in a tumor permissive phenotype. ${ }^{44}$ Aside from deregulation in cancer, SIRT2 has been linked to type II diabetes, ${ }^{45-47}$ bacterial infections, ${ }^{48}$ cardiovascular diseases, ${ }^{49}$ and neurological disorders, $^{50-53}$ thus underlining its potential therapeutic value in the context of drug discovery. Given the fact that there is still much to be learnt about the precise role of SIRT2 in human biology and disease, the availability of well-characterized and selective inhibitors is of prime importance to assist with further validation of this promising target.

A number of small molecule SIRT2 inhibitors have been reported (see Figure 1 for representative examples) including the physiological sirtuin inhibitor nicotinamide (1) and its derivatives, ${ }^{54-56}$ sirtinol (2) and analogues, ${ }^{57}$ cambinol (3), ${ }^{58,59}$ benzamide (4) ${ }^{60}$ and derivative (5), ${ }^{61}$ AGK2 (6), ${ }^{62}$ chroman-4one, ${ }^{63-65}$ and bicyclic pyrazoles (7). ${ }^{66}$ Mechanism-based suicide SIRT2 inhibitors are also known. ${ }^{67-75}$ For the majority of inhibitors, structural details of their binding site and interactions are still lacking. ${ }^{76}$ An exception to this are the aminothiazole analogues ${ }^{77}$ termed the SirReals (such as 8), that were found by crystallography to induce a new selectivity pocket in SIRT2 to yield highly selective SIRT2 inhibitors. The SirReals were subsequently optimized using a structure-based

Received: November 17, 2016

Published: January 30, 2017 

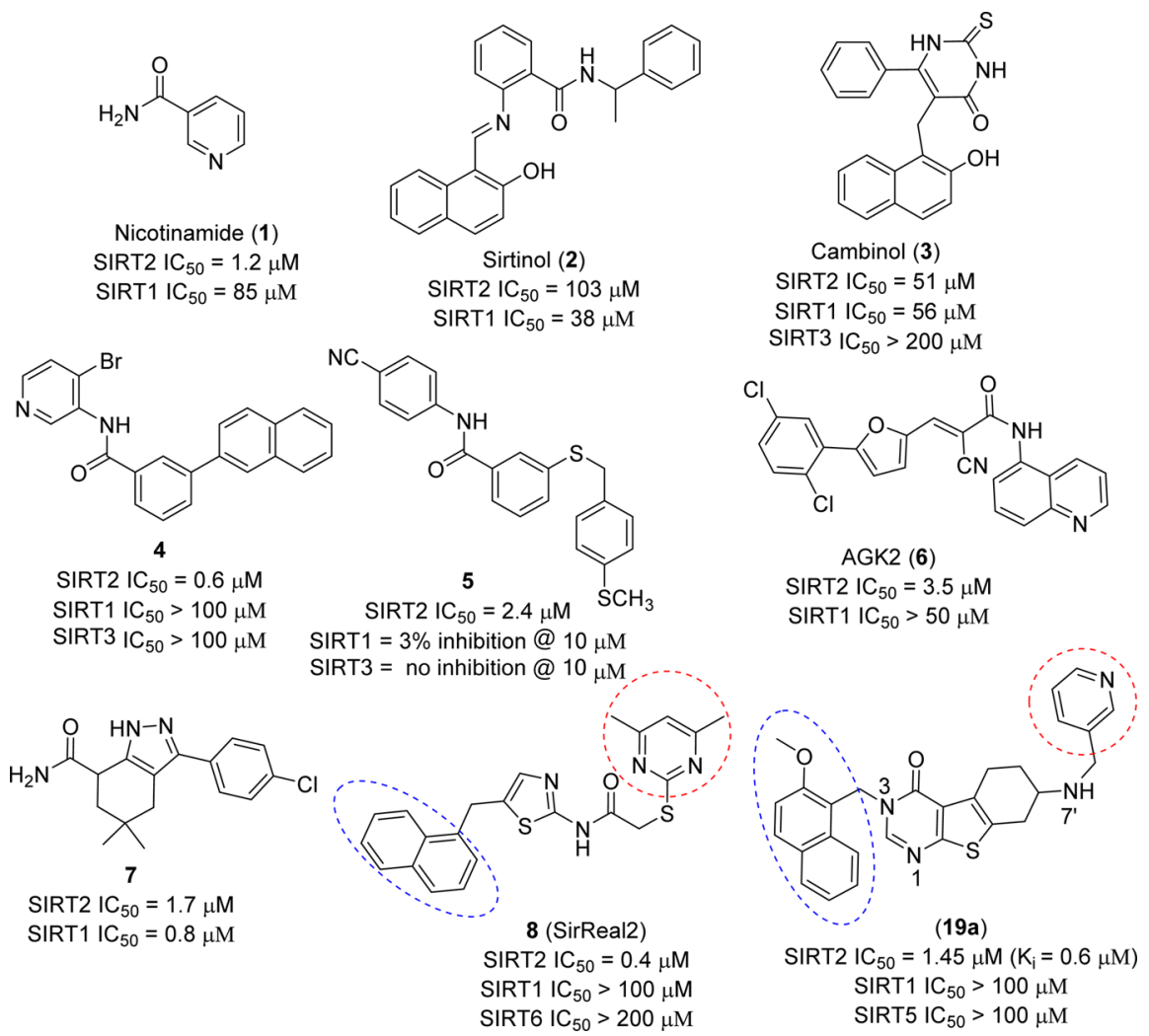

Figure 1. Structures of representative reported sirtuin inhibitors including their $\mathrm{IC}_{50}$ values. The presented $\mathrm{IC}_{50}$ values should be compared with caution, as differing in vitro assays and assay conditions were used to evaluate these compounds. Comparable structural features of SirReal2 (8) and ICL-SIRT078 (19a) are highlighted (see Discussion in the main text).

approach. $^{77-79}$ Consistent with SIRT2 structural rearrangement upon ligand binding, propofol, an injectable hypnotic, was also found to bind to a new allosteric site in SIRT2 which was induced only in the presence of ADP-ribose. ${ }^{80}$

We recently reported highly selective SIRT 2 inhibitors based on the tetrahydrobenzo $[4,5]$ thieno[2,3-d] pyrimidin- $4(3 \mathrm{H})$ one scaffold, which were identified by in silico screening ${ }^{81}$ using a pharmacophore assembled from a previous study ${ }^{82}$ and literature compounds. The identified inhibitor, ICLSIRT078 ${ }^{81}$ (19a, Figure 1), was found to be highly selective for SIRT2 (SIRT2 data: $\mathrm{IC}_{50}$ (fluorogenic peptide) $=1.45 \mu \mathrm{M}$; $\mathrm{IC}_{50}$ (enzyme coupled SIRT-Glo) $=0.17 \mu \mathrm{M} ; K_{\mathrm{i}}$ (tubulinK40 peptide competitive) $=0.62 \mu \mathrm{M}$ ) and showed neuroprotection in a Parkinsonian neuronal cell death model. Only a limited number ( 9 in total) of analogues were examined in the initial paper, particularly with no variation at the eastern $\mathrm{N}-3$ region (see Figure 1) of the inhibitor. A substrate competitive mechanism of action for 19a was inferred from biochemical experiments, but the precise binding pose only predicted from computational docking.

Herein we report a much more extensive SAR study for this series, particularly with a variation at both the N-3 and $\mathrm{N}-7^{\prime}$ positions. Through this, several potent analogues with submicromolar in vitro SIRT2 inhibitory activity have been identified, which retain excellent (>100-fold) selectivity for SIRT2 over SIRT1 and SIRT3. Importantly, we have solved a cocrystal structure of one of our compounds bound to SIRT2. This reveals our compounds to also induce the formation of the selectivity pocket in SIRT2, but to bind in an inverted fashion to what might be intuitively expected from comparison of our series to the SirReal inhibitors (see Figure 1). Using the obtained structure, we have rationalized the SAR for our series and determined an optimum lipophilicity range for inhibitors binding in the induced pocket in SIRT2. As such, this data should prove useful in the further development of refined inhibitors targeting the SIRT2 selectivity pocket.

\section{DISCUSSION}

Structure-Activity Relationship (SAR). The newly synthesized analogues, based on our previously validated thienopyrimidinone scaffold, were designed to contain a variety of N-3 (columns a-i, Table 1) and N-7' substituents (rows 949, Table 1), with the aim to conduct a relatively broad survey of the SAR features of this scaffold. These compounds were all synthesized according to the previously disclosed method ${ }^{81}$ (Schemes SS1 and SS2, Supporting Information) and assessed as racemates. SIRT2 inhibitory activity was assessed using a validated SIRT2 assay, based on a fluorogenic peptide substrate derived from p53 (see Experimental Section). For this assay, suramin was used as a positive control and gave similar inhibitory activity to that observed previously. ${ }^{83} \mathrm{~A}$ vehicle (DMSO) was used as the negative control. SIRT2 inhibitory activity was measured at two compound concentrations, $1 \mu \mathrm{M}$ $(n=2)$ and $10 \mu \mathrm{M}(n=2)$ for all compounds. Full (10-) dose-response SIRT2 IC $_{50}$ values $(n=2)$ were calculated only for selected derivatives that exhibited promising inhibitory activity at $1 \mu \mathrm{M}$.

A quick survey of the tested analogues (Table 1) immediately revealed the importance of a bulky aromatic ring such as naphthalyl (columns a-d), quinolinyl (column e) or biphenyl (column i) at the N-3 position. With limited exceptions, most of the compounds bearing a less bulky benzyl derivative, either 
Table 1. Structures of Thienopyrimidinone Based Inhibitors with SIRT2 Inhibition Data ${ }^{a}$

\begin{tabular}{|c|c|c|c|c|c|c|c|c|c|c|}
\hline $\begin{array}{l}\text { Compd } \\
\text { ID }\end{array}$ & $\stackrel{\mathrm{Ar}}{\longrightarrow}$ & $\mathbf{a}$ & b & $\begin{array}{l}\mathrm{OMe} \\
\mathrm{c}\end{array}$ & d & e & f & g & $\mathbf{h}$ & ร \\
\hline \multirow[t]{3}{*}{9} & & $21.10 \pm 4.30^{b}$ & ND & & $5.45 \pm 0.41$ & $2.50 \pm 0.28$ & $10.42 \pm 1.50$ & ND & ND & \\
\hline & & ND & $66 \%$ & & $71 \%$ & $93 \%$ & $75 \%$ & $57 \%$ & $64 \%$ & \\
\hline & & 5.09 & 5.16 & & 5.16 & 4.28 & 3.89 & 3.96 & 3.89 & \\
\hline \multirow[t]{3}{*}{10} & & $4.07 \pm 0.87^{b}$ & ND & ND & ND & $1.72 \pm 0.12$ & & & & ND \\
\hline & & $73 \%$ & $65 \%$ & $59 \%$ & $56 \%$ & $94 \%$ & & & & $63 \%$ \\
\hline & & 5.19 & 5.26 & 5.19 & 5.26 & 4.38 & & & & 5.72 \\
\hline \multirow[t]{3}{*}{11} & & ND & ND & ND & ND & ND & & & & ND \\
\hline & & $64 \%$ & $71 \%$ & $71 \%$ & $51 \%$ & $49 \%$ & & & & $43 \%$ \\
\hline & & 5.19 & 5.26 & 5.19 & 5.26 & 4.38 & & & & 5.72 \\
\hline \multirow[t]{3}{*}{12} & & ND & ND & ND & ND & $2.84 \pm 1.01$ & & & & ND \\
\hline & & $50 \%$ & $60 \%$ & $-6.5 \%$ & $49 \%$ & $88 \%$ & & & & $43 \%$ \\
\hline & & 5.70 & 5.77 & 5.70 & 5.77 & 4.89 & & & & 6.23 \\
\hline \multirow[t]{3}{*}{13} & & ND & ND & & ND & $1.27 \pm 0.03$ & & & & ND \\
\hline & & $40 \%$ & $64 \%$ & & $49 \%$ & $94 \%$ & & & & $56 \%$ \\
\hline & & 5.70 & 5.77 & & 5.77 & 4.89 & & & & 6.23 \\
\hline \multirow[t]{3}{*}{14} & & ND & ND & ND & ND & $3.80 \pm 0.79$ & & ND & ND & ND \\
\hline & & $40 \%$ & $46 \%$ & $65 \%$ & $43 \%$ & $85 \%$ & & $67 \%$ & $68 \%$ & $39 \%$ \\
\hline & & 5.70 & 5.77 & 5.70 & 5.77 & 4.89 & & 4.57 & 4.50 & 6.23 \\
\hline \multirow[t]{3}{*}{15} & & $\mathrm{ND}$ & $\mathrm{ND}$ & & $\mathrm{ND}$ & $0.39 \pm 0.02$ & & & & ND \\
\hline & & $75 \%$ & $66 \%$ & & $67 \%$ & $97 \%$ & & & & $75 \%$ \\
\hline & & 4.92 & 4.99 & & 4.99 & 4.12 & & & & 5.46 \\
\hline \multirow[t]{3}{*}{16} & & $2.24 \pm 0.37$ & ND & & $4.22 \pm 0.73$ & $5.61 \pm 0.92$ & $9.59 \pm 0.66$ & ND & ND & \\
\hline & $\mathrm{MeO}$ & $89 \%$ & $60 \%$ & & $75 \%$ & $85 \%$ & $72 \%$ & $46 \%$ & $64 \%$ & \\
\hline & & 5.02 & 5.09 & & 5.09 & 4.21 & 3.82 & 3.89 & 3.82 & \\
\hline \multirow[t]{3}{*}{17} & & $1.90 \pm 0.09^{b}$ & ND & & ND & ND & $13.40 \pm 1.32$ & ND & ND & \\
\hline & & ND & $59 \%$ & & $51 \%$ & $78 \%$ & $69 \%$ & $48 \%$ & $58 \%$ & \\
\hline & & 5.02 & 5.09 & & 5.09 & 4.21 & 3.82 & 3.89 & 3.82 & \\
\hline \multirow[t]{3}{*}{18} & & $0.65 \pm 0.03$ & $3.2 \pm 0.52$ & & $3.82 \pm 0.47$ & $1.83 \pm 0.18$ & ND & ND & ND & \\
\hline & $=L^{2}$ & $96 \%$ & $78 \%$ & & $86 \%$ & $95 \%$ & $67 \%$ & $45 \%$ & $71 \%$ & \\
\hline & & 5.02 & 5.09 & & 5.09 & 4.21 & 3.82 & 3.89 & 3.82 & \\
\hline \multirow[t]{3}{*}{19} & & $1.45 \pm 0.1^{\mathrm{b}}$ & $2.99 \pm 0.63$ & & & $2.92 \pm 0.02$ & & ND & ND & \\
\hline & & ND & $89 \%$ & & & $91 \%$ & & $42 \%$ & $27 \%$ & \\
\hline & & 4.09 & 4.16 & & & 3.28 & & 2.96 & 2.89 & \\
\hline \multirow[t]{3}{*}{20} & $\mathrm{~N}-7$ & $1.20 \pm 0.24$ & $3.58 \pm 0.29$ & & $3.14 \pm 0.52$ & $3.68 \pm 0.44$ & ND & ND & ND & \\
\hline & & $95 \%$ & $92 \%$ & & $92 \%$ & $83 \%$ & $64 \%$ & $33 \%$ & $59 \%$ & \\
\hline & & 4.09 & 4.16 & & 4.16 & 3.28 & 2.89 & 2.96 & 2.89 & \\
\hline
\end{tabular}


Table 1. continued

\begin{tabular}{|c|c|c|c|c|c|c|c|c|c|c|}
\hline $\begin{array}{c}\text { Compd } \\
\text { ID }\end{array}$ & $\stackrel{\mathrm{Ar}}{\longrightarrow}$ & a & b & $\begin{array}{l}\text { Öe } \\
\text { c }\end{array}$ & d & e & ${ }^{\mathrm{MeO}}$ II & g & 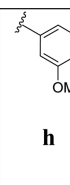 & $\begin{array}{l}\mathbf{i} \\
\underbrace{p h}\end{array}$ \\
\hline \multirow[t]{3}{*}{21} & & $3.12 \pm 0.09$ & $7.68 \pm 1.14$ & & $8.67 \pm 0.59$ & $2.61 \pm 0.16$ & ND & ND & ND & \\
\hline & & $83 \%$ & $81 \%$ & & $81 \%$ & $87 \%$ & $35 \%$ & $26 \%$ & $18 \%$ & \\
\hline & & 4.14 & 4.21 & & 4.21 & 3.33 & 2.95 & 3.02 & 2.95 & \\
\hline \multirow[t]{3}{*}{22} & & ND & $6.45 \pm 0.02$ & & $5.30 \pm 0.11$ & ND & ND & ND & ND & \\
\hline & & $33 \%$ & $86 \%$ & & $88 \%$ & $75 \%$ & $45 \%$ & $18 \%$ & $18 \%$ & \\
\hline & & 3.53 & 3.60 & & 3.60 & 2.72 & 2.33 & 2.40 & 2.33 & \\
\hline \multirow[t]{3}{*}{23} & & $1.9 \pm 0.19$ & $7.59 \pm 0.04$ & & $10.17 \pm 0.94$ & $2.65 \pm 0.35$ & ND & ND & ND & \\
\hline & & $83 \%$ & $75 \%$ & & $76 \%$ & $90 \%$ & $56 \%$ & $48 \%$ & $28 \%$ & \\
\hline & & 4.37 & 4.44 & & 4.44 & 3.56 & 3.18 & 3.25 & 3.18 & \\
\hline \multirow[t]{3}{*}{24} & & $1.65 \pm 0.00$ & & & $5.53 \pm 0.69$ & $2.43 \pm 0.01$ & $9.18 \pm 0.42$ & ND & ND & \\
\hline & & $97 \%$ & & & $87 \%$ & $94 \%$ & $79 \%$ & $56 \%$ & $62 \%$ & \\
\hline & & 5.42 & & & 5.49 & 4.61 & 4.23 & 4.30 & 4.23 & \\
\hline \multirow[t]{3}{*}{25} & & $1.90 \pm 0.09$ & $12.48 \pm 1.34$ & & $13.14 \pm 0.35$ & ND & ND & ND & ND & \\
\hline & & $90 \%$ & $67 \%$ & & $71 \%$ & $58 \%$ & $27 \%$ & $22 \%$ & $3 \%$ & \\
\hline & & 3.97 & 4.04 & & 4.04 & 3.16 & 2.78 & 2.85 & 2.78 & \\
\hline \multirow[t]{3}{*}{26} & & $6.03 \pm 0.10$ & ND & ND & ND & ND & & & & $2.58 \pm 1.45$ \\
\hline & & $85 \%$ & $72 \%$ & $70 \%$ & $58 \%$ & $60 \%$ & & & & $91 \%$ \\
\hline & & 3.92 & 3.99 & 3.92 & 3.99 & 3.11 & & & & 4.45 \\
\hline \multirow[t]{3}{*}{27} & & $5.11 \pm 0.24$ & $4.20 \pm 0.16$ & & $7.43 \pm 0.36$ & ND & ND & ND & ND & \\
\hline & & $94 \%$ & $85 \%$ & & $87 \%$ & $74 \%$ & $37 \%$ & $32 \%$ & $14 \%$ & \\
\hline & & 3.95 & 4.02 & & 4.02 & 3.14 & 2.75 & 2.82 & 2.75 & \\
\hline \multirow[t]{3}{*}{28} & $\hat{C}$ & $5.24 \pm 0.69$ & $7.61 \pm 1.02$ & & $11.68 \pm 1.79$ & $4.16 \pm 0.92$ & ND & ND & $\mathrm{ND}$ & \\
\hline & & $78 \%$ & $70 \%$ & & $72 \%$ & $80 \%$ & $43 \%$ & $33 \%$ & $33 \%$ & \\
\hline & & 4.28 & 4.35 & & 4.35 & 3.47 & 3.08 & 3.15 & 3.08 & \\
\hline \multirow[t]{3}{*}{29} & & $4.00 \pm 0.41$ & $1.85 \pm 0.14$ & $0.58 \pm 0.02$ & ND & $6.94 \pm 0.03$ & & & & ND \\
\hline & & $87 \%$ & $85 \%$ & $96 \%$ & $67 \%$ & $80 \%$ & & & & $60 \%$ \\
\hline & & 4.30 & 4.37 & 4.30 & 4.37 & 3.49 & & & & 4.83 \\
\hline \multirow[t]{3}{*}{30} & & $6.03 \pm 2.25^{\mathrm{b}}$ & ND & ND & ND & $2.56 \pm 0.11$ & & & & ND \\
\hline & & $69 \%$ & $54 \%$ & $71 \%$ & $62 \%$ & $88 \%$ & & & & $66 \%$ \\
\hline & & 4.96 & 5.03 & 4.96 & 5.03 & 4.15 & & & & 5.49 \\
\hline \multirow[t]{3}{*}{31} & & $10.31 \pm 2.0$ & $9.57 \pm 0.82$ & & $8.68 \pm 0.93$ & & ND & ND & $\mathrm{ND}$ & \\
\hline & & $66 \%$ & $80 \%$ & & $77 \%$ & & $38 \%$ & $27 \%$ & $40 \%$ & \\
\hline & & 4.52 & 4.59 & & 4.59 & & 3.32 & 3.39 & 3.32 & \\
\hline \multirow[t]{3}{*}{32} & & $2.75 \pm 0.0$ & $5.79 \pm 0.50$ & & $9.60 \pm 0.70$ & & $\mathrm{ND}$ & ND & ND & \\
\hline & & $95 \%$ & $75 \%$ & & $72 \%$ & & $26 \%$ & $18 \%$ & $39 \%$ & \\
\hline & & 4.52 & 4.59 & & 4.59 & & 3.32 & 3.39 & 3.32 & \\
\hline
\end{tabular}


Table 1. continued

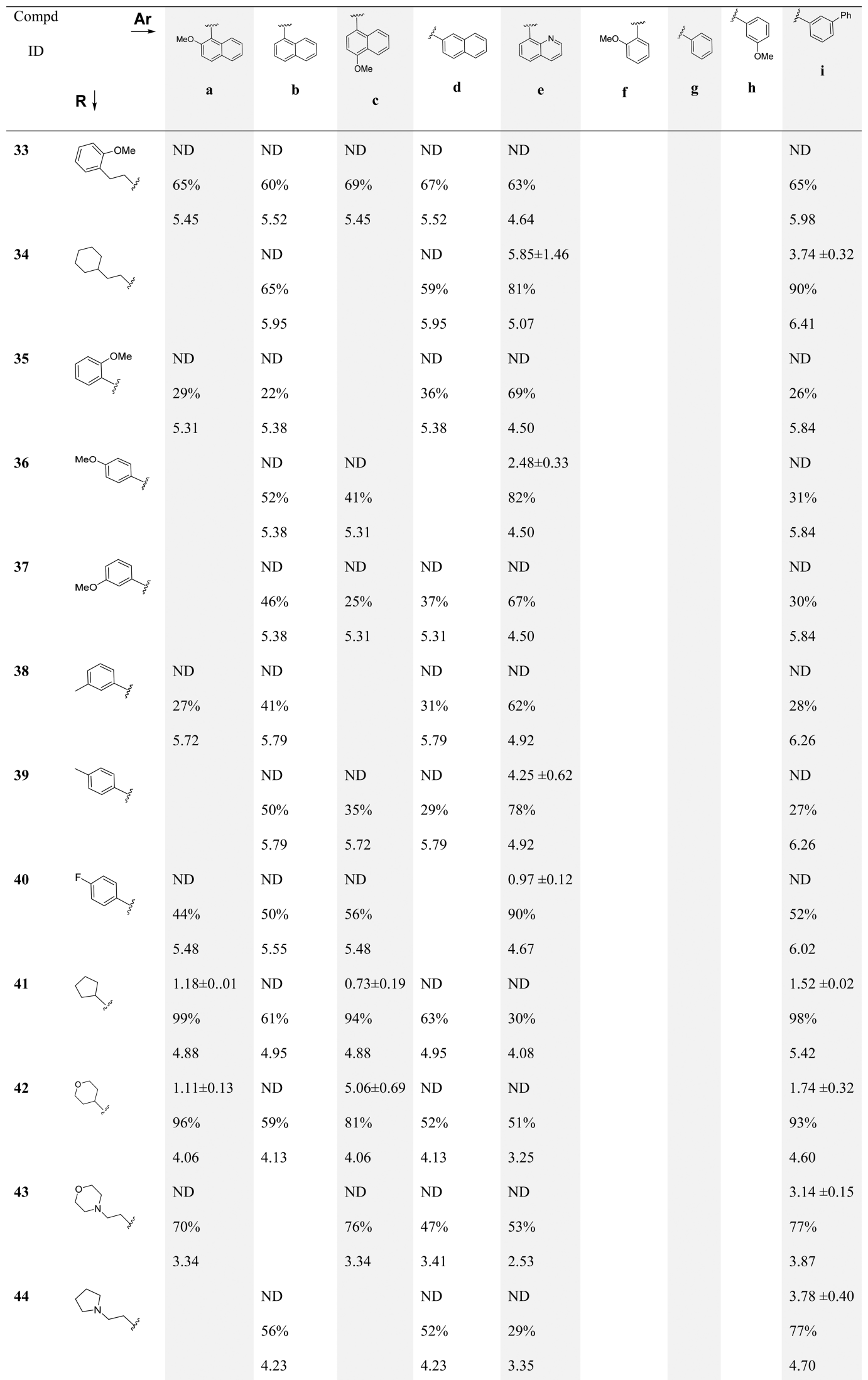


Table 1. continued

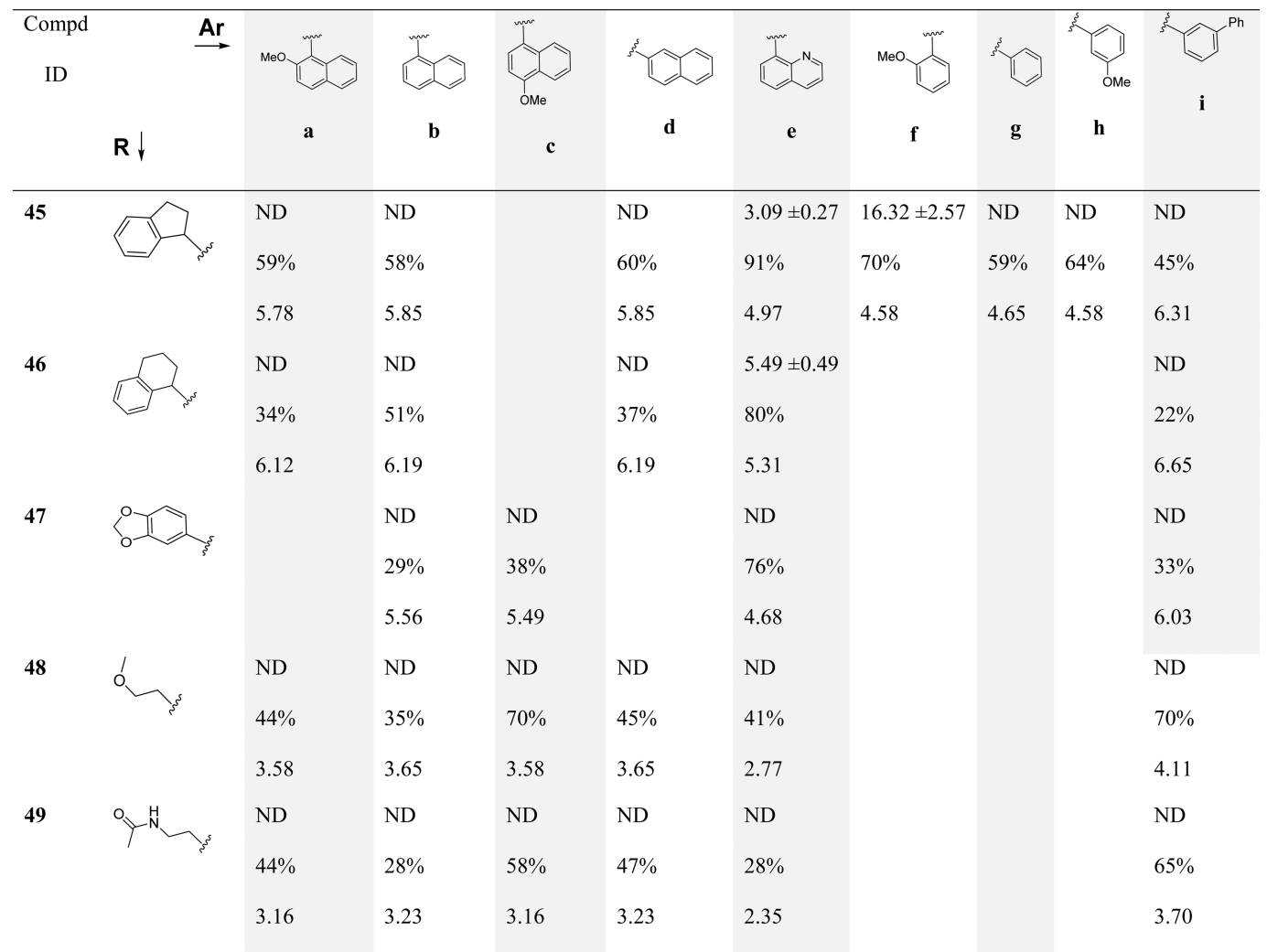

${ }^{a}$ In each cell, the top value is $\mathrm{IC}_{50}(\mu \mathrm{M})$, the middle value is percentage inhibition (at $10 \mu \mathrm{M}$ ), and the bottom value is cLogP; ND = not determined. Errors represent the standard deviation, calculated from two replicates. Empty cells mean that the compound was not synthesized/ tested. ${ }^{b}$ Compounds reported earlier ${ }^{81}$

an $o$ - or $m$-methoxybenzyl (columns $\mathbf{f}$ and $\mathbf{h}$ ) or an unsubstituted benzyl (column g), at N-3 displayed poor SIRT2 inhibition, in comparison to the analogues possessing a bicyclic ring or a biphenyl moiety at this position. The most notable examples are $16 \mathrm{a} / \mathrm{d} / \mathrm{e}$ vs $16 \mathrm{~g} / \mathrm{h} ; 18 \mathrm{a} / \mathrm{b} / \mathrm{d} / \mathrm{e}$ vs $18 \mathrm{~g} / \mathrm{h}$; $20 a / b / d / e$ vs $20 \mathrm{~g} / \mathrm{h} ; 23 \mathrm{a} / \mathrm{e}$ vs $23 \mathrm{f}-\mathrm{h}$; or $25 \mathrm{a}$ vs $25 \mathrm{f}-\mathrm{h}$. This SAR feature was observed in an early phase of our SAR study, and hence, we did not pursue the further synthesis of benzyl based derivatives for other N-7' R substituents, as evident from the empty cells under columns $\mathbf{f}-\mathbf{h}$ in Table 1 .

The effect of substitution at the $\mathrm{N}-7^{\prime}$ position on SIRT2 inhibitory activity was found to be dependent on the type of $\mathrm{N}-3$ substituent. For example, the presence of a benzyl ring at $\mathrm{N}-7^{\prime}$ (row 9) yielded molecules with only moderate activity in combination with almost all of the N-3 substituents except 8-quinolylmethylene $\left(9 \mathrm{e}, \mathrm{SIRT} 2 \mathrm{IC}_{50}=2.5 \mu \mathrm{M}\right)$ and to a lesser extent 2-naphthyl (9d, SIRT2 $\left.\mathrm{IC}_{50}=5.45 \mu \mathrm{M}\right)$. With more polar aromatic rings at $\mathrm{N}-7^{\prime}$, interesting trends were observed. Electron withdrawing halogenated rings at $\mathrm{N}-7^{\prime}$ (rows 10-14) yielded poor to moderate inhibitors (SIRT2\% inhibition = $40-70 \%$ at $10 \mu \mathrm{M}$ ) with the naphthyl (columns a-d) or biphenyl-based (column i) N-3 substituents, whereas improved SIRT inhibitory activity of these derivatives was observed when there was a 8-quinolylmethylene N-3 substituent (column e). Examples include, $10 \mathrm{e}$ vs $10 \mathrm{a}-\mathrm{d} ; 12 \mathrm{e}$ vs $12 \mathrm{a}-\mathrm{d}$; $13 \mathrm{e}$ vs $13 \mathrm{a}-\mathrm{c}$; and $14 \mathrm{e}$ vs $14 \mathrm{a}-\mathrm{d}$. Furthermore, 8-quinolylmethylene N-3 substituted molecules exhibited very similar $\mathrm{IC}_{50}$ values between a substituted benzyl group at $\mathrm{N}-7^{\prime}$ and halogenated rings at $\mathrm{N}-7^{\prime}$, for example, 9e vs 10e, 12e-14e. A similar observation was made with the 4-cyanobenzyl N-7' substituent, which, in combination with 8-quinolylmethylene, yielded $15 \mathrm{e}$, a compound with submicromolar SIRT2 inhibitory activity (SIRT2 IC $\left._{50}=0.39 \mu \mathrm{M}\right)$. Conversely, only moderate activity (SIRT2\% inhibition $=66-75 \%$ at $10 \mu \mathrm{M}$ ) was observed for compounds bearing a 4-cyanobenzyl N-7' substituent in the presence of other N-3 substituents (for example, 15a, 15b, 15d, and $\mathbf{1 5 i}$ ).

The effect of an electron donating methoxy substitution on the $\mathrm{N}-7^{\prime}$ benzyl group seemed to improve the activity of molecules possessing a 2-methoxy-naphthalen-1-yl N-3 substituent (column a) compared to the other $\mathrm{N}-3$ substituents. For example, 16a, 17a, and 18a displayed a 9-, 11-, and 32-fold increase in potency, over 9a, respectively. Interestingly, a similar improvement was not observed with the 8-quinolylmethyl N-3 substituent (column e). For instance, in comparison to the unsubstituted benzyl inhibitor $\left(9 \mathrm{e}\right.$, SIRT2 $\left.\mathrm{IC}_{50}=2.50 \mu \mathrm{M}\right)$, the $o$-methoxy benzyl analogue (16e) exhibited poorer potency (SIRT2 IC $_{50}=5.61 \mu \mathrm{M}$ ), while the $p$-methoxy benzyl analogue (18e) exhibited only a slight improvement in SIRT2 inhibition (SIRT2 $\left.\mathrm{IC}_{50}=1.83 \mu \mathrm{M}\right)$. In general, analogues containing a p-methoxy benzyl N-7' substituent consistently showed better SIRT2 inhibition compared to that of the $o$-methoxy or $m$-methoxy analogues (18 vs 16/17). In particular, 18a exhibited potent SIRT2 inhibition compared to that of other methoxy substituted analogues with a submicromolar SIRT2 $\mathrm{IC}_{50}$ value of $0.65 \mu \mathrm{M}$.

The hit compound that initated this study, $19 a{ }^{81}$ has a 3-pyridylmethylene substituent at the $\mathrm{N}-7^{\prime}$ and has good inhibitory activity against SIRT2 $\left(\mathrm{IC}_{50}=1.45 \mu \mathrm{M}\right.$ in the same assay format as this study). Changing the position of pyridyl 
nitrogen did not have any dramatic effect on the observed activity except that 2-pyridyl (row 21) analogues exhibited slightly weaker SIRT2 inhibition than the other two pyridyl substituents (apart from the derivative bearing a 7-quinolylmethylene substituent), for example, 21a vs 19a/20a. Compounds 19a and 20a with the 2-methoxy-naphthalen-1-yl substituent at N-3 were found to be the most potent in this category, with low micromolar activity (SIRT2 $\mathrm{IC}_{50}=1.45$ and $1.20 \mu \mathrm{M}$, respectively). Replacing the pyridine ring of $\mathrm{N}-7^{\prime}$ with a pyrimidine ring (row 22) resulted in either poor $(\mathbf{2 2 a} / \mathbf{f}-\mathbf{h})$ or moderate $(\mathbf{2 2 b} / \mathbf{d} / \mathbf{e})$ SIRT2 inhibition. Interestingly, analogues containing a 6-methoxypyridin-3-yl (row 23) $\mathrm{N}-7^{\prime}$ substituent exhibited activities similar to those with a 2-pyridyl N-7' substituent (row 21).

An aliphatic cyclic or saturated heterocyclic ring at N-3 (rows 24-26), led to a series of derivatives where only a combination of these substituents with a 2-methoxy-naphthalen-1-yl $\mathrm{N}-7^{\prime}$ substituent (column a) was found to give effective SIRT2 inhibitors. For example, analogues with pendent cyclohexyl (24a) or tetrahydrofur-2-yl rings (25a) at N-7' gave $\mathrm{IC}_{50}$ values lower than $2 \mu \mathrm{M}$ in the presence of a 2-methoxy-naphthalen-1-yl $\mathrm{N}-3$ substituent. A variety of derivatives bearing five membered heteroaromatic rings at $\mathrm{N}-7^{\prime}$, such as pyrazole (row 27), furan (row 28), isoxazole (row 29), and thiophene (row 30), were also evaluated. Most of the tested analogues in this series showed moderate to poor activity. An important outlier, however, was isoxazole 29, with a 4-methoxy-naphthalen-1-yl group in the $\mathrm{N}-7^{\prime}$ : 29c had a submicromolar $\mathrm{IC}_{50}$ value of $0.58 \mu \mathrm{M}$.

Next, we evaluated the effect of the number of linker carbons between the core ring system and the $\mathrm{N}-7^{\prime}$ substituent. In general, increasing the linker chain from one (rows 9-30) to two carbons (rows 31-34) had a slightly deleterious effect on the SIRT2 inhibition, for example, $16 a$ vs $33 a ; 19 b$ vs $31 b$; and $20 a / b / d$ vs $32 a / b / d$. Likewise, aromatic N-7' substituents without a linker carbon (rows 35-40) exhibited reduced potency, especially in comparison to their counterparts attached with a one carbon linker. For example, analogues $35 \mathbf{a} / \mathbf{b} / \mathbf{d}$ vs $16 a / b / d$ and $36 b$ vs $18 b$. However, in combination with the 8-quinolylmethyl N-3 substituent the activity of analogues with these $\mathrm{N}-7^{\prime}$ aromatic rings was somewhat rescued, as exemplified by $35 \mathbf{e}-40 \mathbf{e}$; most potent being $40 \mathrm{e}$ with a 4 -fluorophenyl ring (SIRT2 $\mathrm{IC}_{50} 0.97 \mu \mathrm{M}$ ). This trend was not maintained, however, for analogues with aliphatic rings (rows 41-42) directly attached to the $\mathrm{N}-\mathrm{7}^{\prime}$ position. Such derivatives exhibited good activity in combination with 2-methoxy-naphthalen-1-yl (column a), 4-methoxy-naphthalen-1-yl (column c) and biphenyl-3-yl (column i), at the N-3 position. Particularly, analogues 41a, 41c, 41i, 42a, and 42i exhibited SIRT2 IC $_{50}$ values in the range of $0.73-1.74 \mu \mathrm{M}$. When the aliphatic ring at $\mathrm{N}-7^{\prime}$ was more polar, particularly containing a basic nitrogen atom directly attached to $\mathrm{N}-7^{\prime}$ via a two carbon linker, only moderately active $(43 a / c / i, 44 i)$ or inactive analogues $(43 d / e$ and $44 \mathrm{~b} / \mathrm{d} / \mathrm{e})$ were obtained.

Bulky N-7' substituents such as dihydro- $1 H$-indenyl (45), tetrahydronaphthalen-1-yl (46) and benzodioxolyl (47) were also found to be detrimental to the SIRT2 inhibition except when in combination with the quinolin-8-yl substituent (column e) at the $\mathrm{N}-3$ position. All three analogues, $45 \mathbf{e}-47 \mathbf{e}$, exhibited moderate SIRT2 inhibition, as compared to other analogues in these rows. Finally, two series of molecules with less bulky and linear (rather than cyclic) N-7' substituents were assessed (row 48 and 49) and were found to possess poor SIRT2 inhibitory activity in most of the cases except $48 \mathrm{c} / \mathbf{i}$ and $49 \mathbf{i}$.
We also synthesized a few analogues where the fused cyclohexyl ring in the central thienopyrimidinone core ring had been ring opened. These derivatives possessed a 2-methoxynaphthalen-1-yl substituent at $\mathrm{N}-3$ end and varying $\mathrm{N}-7^{\prime}$ substituents (50-57, Table 2). These analogues were consistently

Table 2. Analogues Lacking a Fused Cyclohexyl Ring Fused in the Thienopyrimidinone Core ${ }^{a}$

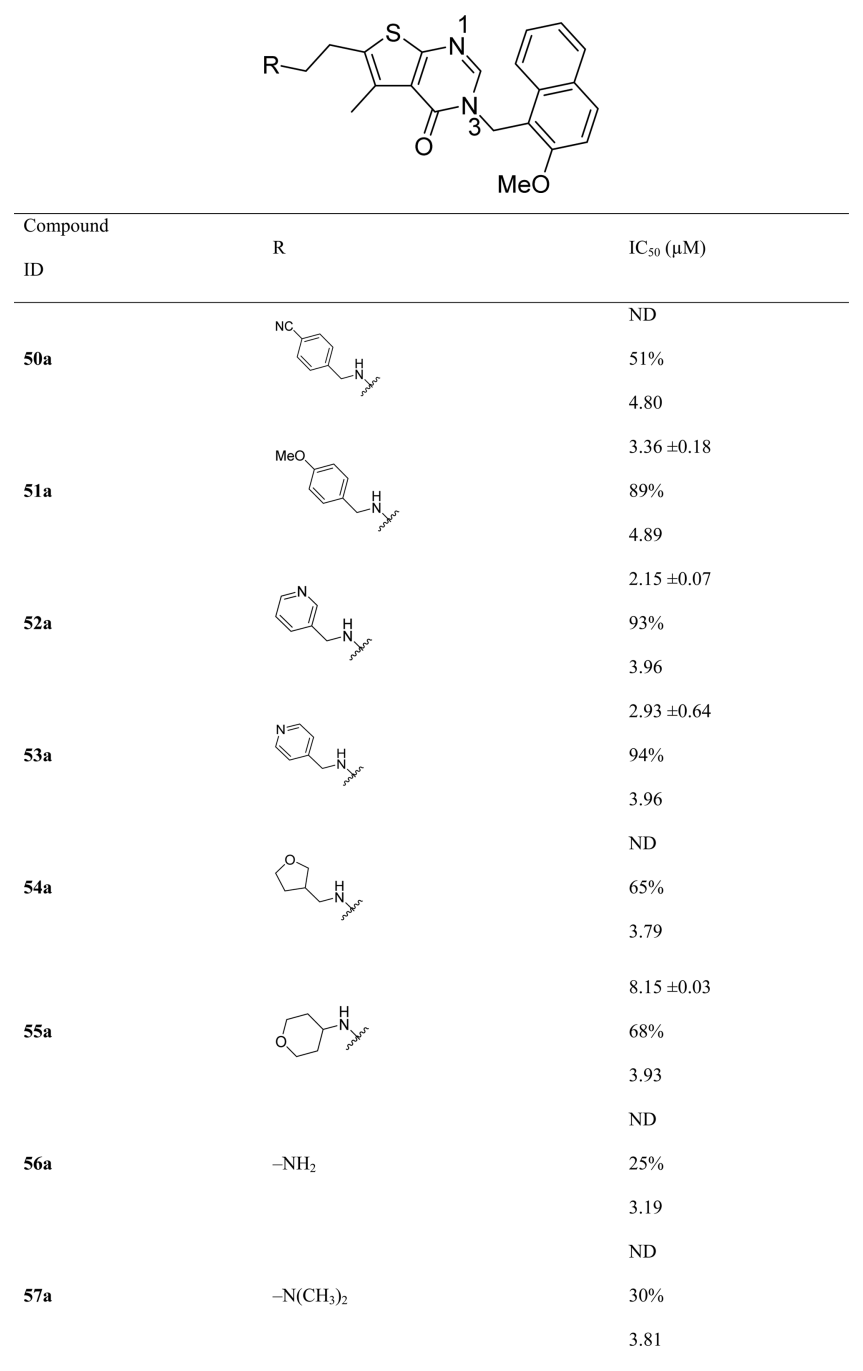

${ }^{a}$ In the last column, the top value is $\mathrm{IC}_{50}(\mu \mathrm{M})$, the middle value is the percentage inhibition (at $10 \mu \mathrm{M})$, and the bottom value is cLogP; ND $=$ not determined. Errors represent the standard deviation, calculated from two replicates.

found to be of slightly lower potency in comparison to that of the corresponding analogues of the original scaffold, for example, 50 a vs $15 a, 51$ a vs $18 a, 52 a$ vs $19 a, 53 a$ vs $20 a, 54 a$ vs $26 a$, and $55 a$ vs $42 a$. The only slightly reduced activity of $51 a-53 a$ relative to the original scaffold suggests that the fused cyclohexyl ring and hence the chiral center at position 7 in the central core is not an essential feature of the SAR. Indeed, we previously found only a relatively small difference in the SIRT2 inhibitory values for enantiomers of $19 a^{81}$ Comparable derivatives lacking an N-7' substituent (56a) or with a smaller dimethylamino (57a) substituent were found to be inactive.

Overall, this SAR analysis suggests that a lipophilic and large bicyclic (column a-e) or biphenyl (column i) N-3 substituent 
is a key requirement for SIRT2 inhibition for this series, while a wide variety of substituents with varying polarity and linker length are tolerated at $\mathrm{N}-7^{\prime}$. This suggests that the vector from $\mathrm{N}-7^{\prime}$ projects into a relatively large pocket and that the $\mathrm{N}-7^{\prime}$ substituent is not involved in any direction-dependent interactions, such as hydrogen bonds or dipole-dipole contacts. The significant SIRT2 inhibition also exhibited by analogues where the fused cyclohexyl ring of the core had been ring opened (50a-55a, Table 2) additionally demonstrates the accommodating nature of the SIRT2 binding pocket in this region.

Dependence of SIRT2 Inhibitory Activity on CLogP. One clear but confounding feature of the SAR above was that some N-7' substituents showed good activity with only certain $\mathrm{N}-3$ substituents, but not with others, and that the optimum $\mathrm{N}-3$ substituent varied depending on $\mathrm{N}-7^{\prime}$ (Table 1, vide supra). We reasoned that different combinations of $\mathrm{N}-7^{\prime}$ and $\mathrm{N}-3$ substituents might be affecting the overall physicochemical parameters of a given molecule making it suitable for binding to the given target SIRT2 pocket. Since, the SAR analysis suggested a potential SIRT2 pocket for these inhibitors to be hydrophobic in nature, we pursued a correlation between the calculated $\log \mathrm{P}(\mathrm{cLog} \mathrm{P})$ of the inhibitors with their activity. Plotting the cLogP of analogues against their SIRT2 inhibitory activity (percentage inhibition at $10 \mu \mathrm{M}$ ) suggested that the inactive analogues ( $<50 \%$ inhibition) possess either high or low cLogP values, when compared to that of the active inhibitors (>80\% inhibition), which generally have cLogP values between 3.8 and 5.3 (Figure 2). We further categorized the analogues

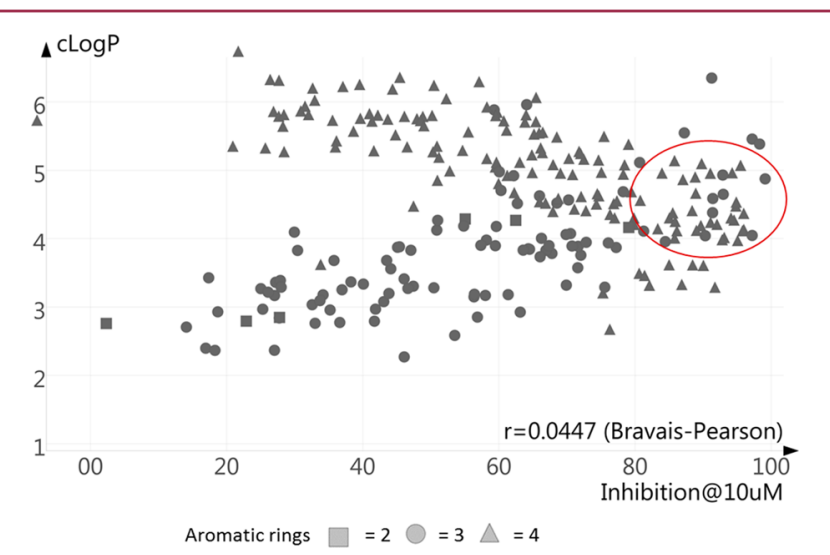

Figure 2. Plot of $c \log \mathrm{P}$ vs percentage inhibition (at $10 \mu \mathrm{M}$ ) for all analogues. Active molecules have 3/4 aromatic rings and lie within the cLogP range $3.8-5.3$ (circled). The analysis was performed in Datawarrior (version 4.4.3) ${ }^{102}$

based on total aromatic ring count, which clearly affects the cLogP of the analogues in this series. Interestingly, analogues with less than 4 aromatic rings showed a positive correlation $(r$ $=0.701$, Figure SF1, Supporting Information), while those with 4 aromatic rings showed a negative correlation $(r=-0.708$, Figure SF2, Supporting Information) with cLogP values. Further categorizing of the data based on the N-3 substituents revealed even higher correlation between cLogP and the activity of analogues with benzyl-based N-3 substituents (Figure SF3, Supporting Information). Overall, with few exceptions most of the active analogues in this series lie in a narrow region of cLogP and possess 3-4 aromatic rings. Analogues which do not fit this criteria are poor SIRT2 inhibitors. This requirement is likely governed by the overall hydrophobic nature of the SIRT2 pocket to which these inhibitors bind.
This analysis explains several puzzling features of the SAR. For instance, most of the analogues based on benzyl or methoxybenzyl (f-h) N-3 substituents possess lower cLogP due to a lower number of aromatic rings (2-3) and thus are inactive. However, improved SIRT2 inhibition for these compounds can be observed when $\mathrm{N}-7^{\prime}$ is occupied by a lipophilic substituent, as in the case of 25f (27\% inhibition@10 $\mu \mathrm{M}$, cLogP $=2.78)$ vs 24f (79\% inhibition@10 $\mu \mathrm{M}, \mathrm{cLogP}=4.23)$ and 45f (70\% inhibition@10 $\mu \mathrm{M}, 4.58) ; 22 \mathrm{~g}$ (18\% inhibition@ $10 \mu \mathrm{M}, \operatorname{cLog} \mathrm{P}=2.40)$ vs 14g $(67 \%$ inhibition@10 $\mu \mathrm{M}, \operatorname{clog} \mathrm{P}=$ 4.57); 25h (3\% inhibition@10 $\mu \mathrm{M}, \operatorname{clog} \mathrm{P}=2.78)$ vs $\mathbf{1 8 h}$ (71\% inhibition@10 $\mu \mathrm{M}$, clogP = 3.82), and so on.

Likewise, replacing the less lipophilic quinolin-8-yl (column e) with a biphenyl (column i) or methoxynaphthyl (column a, c) at $\mathrm{N}-7^{\prime}$ can improve the activity of analogues having a more polar $\mathrm{N}-3$ substituent, for instance, 42e (51\% inhibition@10 $\mu \mathrm{M}$, cLogP = 3.25) vs 42a (96\% inhibition@10 $\mu \mathrm{M}, \mathrm{cLog} \mathrm{P}=4.06)$ and 42i (93\% inhibition@10 $\mu \mathrm{M}$, cLogP = 4.60); 43e (53\% inhibition@10 $\mu \mathrm{M}, \operatorname{cLogP}=2.53)$ vs 43a (70\% inhibition@10 $\mu \mathrm{M}, \mathrm{cLog} \mathrm{P}=3.34), 43 \mathrm{c}(76 \%$ inhibition@10 $\mu \mathrm{M}, \mathrm{cLog} \mathrm{P}=$ 3.34), and 43i (77\% inhibition@10 $\mu \mathrm{M}, \operatorname{cLog} \mathrm{P}=3.87)$; 44e (29\% inhibition@10 $\mu \mathrm{M}, \operatorname{cLog} \mathrm{P}=3.35)$ vs 44i $(77 \%$ inhibition@10 $\mu \mathrm{M}, \mathrm{cLogP}=4.70)$. Conversely, replacement of quinolin-8-yl with more lipophilic N-3 substituents can also render active molecules inactive by raising the clogP values above the optimum level. For example, 12e (88\% inhibition@10 $\mu \mathrm{M}$, cLogP $=4.89)$ vs 12a/c/d/i; 13e (94\% inhibition@10 $\mu \mathrm{M}, \operatorname{cLog} \mathrm{P}=4.89)$ vs $13 \mathrm{a} / \mathrm{d} / \mathbf{i}$; 14e (85\% inhibition@10 $\mu \mathrm{M}$, cLogP $=4.89)$ vs $14 \mathbf{a} / \mathbf{b} / \mathbf{i} ; 15 e$ (97\% inhibition@10 $\mu \mathrm{M}$, cLogP $=4.12)$ vs 15a/b/d/i; 40e (90\% inhibition@10 $\mu \mathrm{M}, \operatorname{cLog} \mathrm{P}=4.67)$ vs 40a/c/i; 45e (91\% inhibition@10 $\mu \mathrm{M}$, cLogP $=4.97)$ vs 45b/i and 46e (80\% inhibition@10 $\mu \mathrm{M}$, cLogP $=5.31)$ vs $46 a / d / i$.

X-ray Structure and Molecular Docking Study. During the course of this work, the aminothiazole based SIRT2 inhibitor 8 (Figure 1) was reported by Rumpf et al. $^{77}$ which shared some structural similarity with our original hit molecule 19a. Notably, both molecules possess a naphthyl ring attached to one end of a heterocyclic central scaffold, with a nitrogen rich heterocycle on the opposite end (see Figure 1). Corresponding to the SAR disclosed in this study, an analogue of compound 8 possessing a benzyl ring (SirReal1) in place of the naphthyl ring was shown to be less active against SIRT2. ${ }^{77}$ Also, both series of molecules exhibited high SIRT2 selectivity over other isoforms that cannot be readily explained by hotspot analysis of residues in the binding pocket. ${ }^{84}$ On the basis of these SAR similarities, we hypothesized that our thienopyrimidinone based inhibitors might also bind in the SIRT2 active site by inducing the same selectivity pocket as $\mathbf{8}$. Docking our highly active thienopyrimidinone analogues into the 8 bound SIRT2 structure (PDB $4 \mathrm{RMH})^{77}$ (with the ligand removed) indeed showed poses with overlap between the naphthyl groups of 8 and some of our active analogues. However, the N-7' substituent was not found to occupy the selectivity pocket in many cases (data not shown). Additionally, other SAR trends could not be readily explained by docking our analogues into this structure (PDB 4RMH).

In parallel, we pursued the characterization of SIRT2 inhibitor binding for our series by X-ray crystallography. Pleasingly, we managed to obtain the SIRT2 structure cocrystallized with compound 29c. This new SIRT2 crystal form, obtained in the absence of substrate or cosubstrate, belongs to a monoclinic space group and contains two molecules of SIRT2 in the asymmetric unit (AU). Both copies share a very similar 
conformation (rmsd $0.31 \AA$ over $215 \mathrm{C} \alpha$ atoms), which is also closely related to the structures of SIRT2 in complex with 8 (rmsd ranging from 0.53 to $0.70 \AA$ over $216 \mathrm{C} \alpha$ atoms). Only one of the two SIRT2 molecules of the AU is bound to 29c (Figure 3a). The second SIRT2 molecule, although in a very
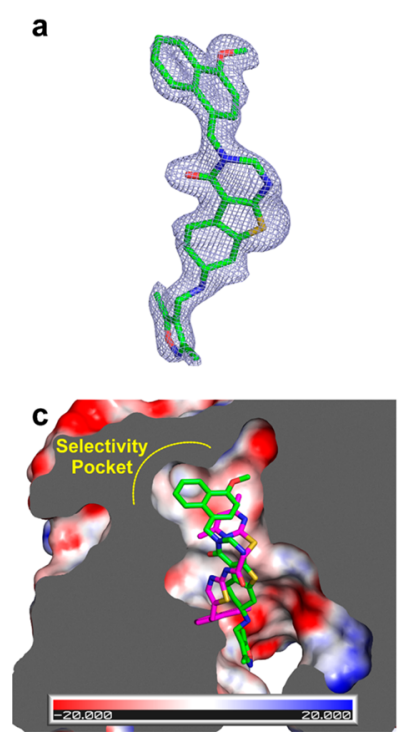
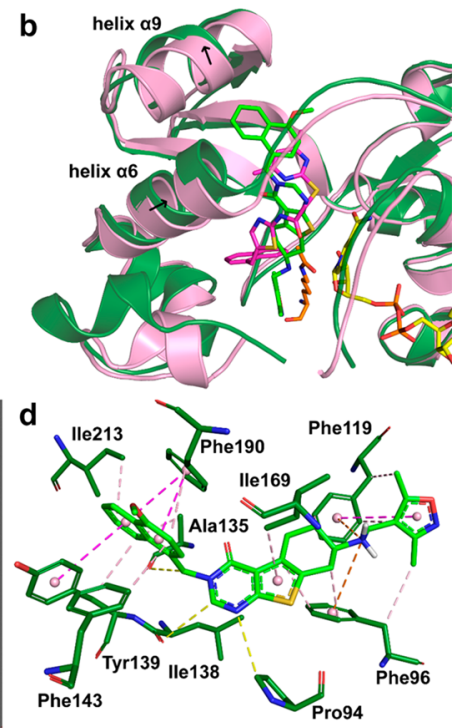

Figure 3. (a) 29c bound to SIRT2 is represented in green sticks in the Fourier difference omit electron density map ( $\mathrm{mFo}-\mathrm{DFc})$ contoured at $3 \sigma$. (b) X-ray structure of SIRT2 (green ribbons) bound to 29c (green sticks). Previously reported SIRT2 structure (pink ribbons, PDB 4RMG) co-crystallized with 8 (pink sticks) and $\mathrm{NAD}^{+}$(yellow sticks) is also shown for comparison. The acyl-lysine (orange stick) represents the position of the substrate in the superposed structure of SIRT3 (ribbon not shown) in complex with AceCS2 peptide (PDB 3GLR). (c) Electrostatic surface of SIRT2 illustrating the hydrophobic selectivity pocket induced by 4-methoxy-naphthalen-1-yl ring of 29c. The electrostatic potential was calculated using the APBS plugin ${ }^{108}$ of Pymol and represented on the surface of the protein with a scale ranging from -20 (red) to 20 (blue) $\mathrm{KbT} / \mathrm{Ec}$. The naphthyl ring of 29c buries more deeply into the selectivity pocket in comparison to the dimethylpyrimidine (DMP) ring of $\mathbf{8}$. The dimethylisoxazole (DMI) group of 29c occupies a wide channel and extends toward the entry of the substrate binding pocket. (d) Interactions of analogue 29c within the SIRT2 pocket. The naphthyl ring forms $\pi$ - $\pi$ interactions (magenta dashed lines) with Tyr139 and Phe190, while the isoxazole moiety forms a $\pi-\pi$ stacking interaction with Phe119. The protonated $\mathrm{N}-7^{\prime}$ amino group maintains $\pi$-cation interactions (orange dashed lines) with Phe119 and Phe96. Various hydrophobic interactions are represented by the light pink dashed lines. Non classical $\mathrm{C}-\mathrm{H}$ hydrogen bonds between 29c and Ala135, Leu138, and Pro94 are shown by yellow dashed lines. For clarity, only interacting amino acid residues are shown. Images were generated using the PyMOL Molecular Graphics System, version 1.7 Schrödinger, LLC.

similar conformation, showed noisy electron density maps presumably arising from low occupancy and/or multiple conformations of the inhibitor (racemate) and thus did not allow for confident modeling. For the well-defined SIRT2 bound structure of 29c, the inhibitor was found to bind at the interface of the NAD-binding domain and the zinc-binding domain, by inducing the selectivity pocket in the extended C-site (Figure $3 \mathrm{~b}$ and Figure SF4, Supporting Information). This binding mode is consistent with the mechanism of inhibition observed for the hit compound that initiated this study (19a) and closely related to the inhibition mode of $8 .^{77}$ However, the pose of $29 \mathrm{c}$ inside the pocket is inverted from what may be expected based on its structural similarity to 8 (Figure 1) and our initial docking studies. Unlike 8, analogue 29c induces the selectivity pocket through its 2-methoxy-naphthalen-1-yl ring and positions itself deeper into the cavity created between helices $\alpha 6$ (129-138) and $\alpha 9(206-215)$ of the zinc binding domain (Figure $3 \mathrm{~b}$ and c), forming favorable hydrophobic and $\pi-\pi$ contacts with the selectivity pocket residues (Figure 3d and Figure SF5, Supporting Information). In order to accommodate the bulkier naphthyl ring of 29c, repositioning of $\alpha 9$ by $1.3 \AA$ and reorientation of the side chains of selectivity pocket residues Tyr139, Pro140, Phe190, Leu206, Lys210, and Phe214 are observed in comparison to the structure of SIRT2 with $\mathbf{8}$ bound (Figure SF6, Supporting Information).

The plane of the thienopyrimidinone ring of 29c is perpendicular to the 4-methoxy-naphthalen-1-yl ring and occupies a hydrophobic region adjacent to the $\mathrm{NAD}^{+}$binding pocket, making contacts with Ile93, Pro94, Phe96, and Ile169 (Figure SF5 and SF7, Supporting Information). The N-7'dimethylisoxazole (DMI) substituent of 29c extends toward the entry of the substrate binding pocket and interacts with Phe96 and Phe119 through $\pi-\pi$ as well as hydrophobic interactions (Figure SF5 and SF7 Supporting Information). Like compound 8 , the overall binding of $29 \mathrm{c}$ in the SIRT2 active site is driven by $\pi-\pi$ stacking, hydrophobic interactions, and van der Waals (vdW) contacts. Stacking on top of the thienopyrimidinone ring of 29c, the so-called gate keeper Phe96 side chain, which assists nicotinamide release and prevents backward reaction, is blocked in a conformation compatible with $\mathrm{NAD}^{+}$binding, consistent with the noncompetitive mode of inhibition for the cosubstrate observed for $19 a^{81}$ The DMI partially occupies the position of the acetyl group of the substrate, also consistent with the competitive mode of inhibition of $19 \mathrm{a}$ with the substrate peptide (Figure SF8, Supporting Information). ${ }^{81}$

The SIRT2 bound conformation of $29 \mathrm{c}$ and its interaction within the selectivity pocket also explains the observed SAR for this series. For instance, most of the analogues having a bicyclic ring (Table 1, columns $\mathbf{a}-\mathbf{e}$ ) or a biphenyl (column i) at N-3 were found to have stronger SIRT2 inhibition compared to that of the analogues with a benzyl or substituted benzyl group (column $\mathbf{f}-\mathbf{h}$ ) in this region. This might be due to the stronger hydrophobic/vdW contacts exhibited by the bulky aromatic rings in the selectivity pocket in the case of $\mathbf{a}-\mathbf{e} / \mathbf{i}$ compared to the less lipophilic benzyl group. This is further supported by the fact that analogues such as $14 \mathrm{~g} / \mathbf{h}$ and $\mathbf{4 5 f}-\mathbf{h}$, are less active even though they lie in the optimum cLogP range (vide supra). Indeed, docked poses of analogues with a benzyl $\mathrm{N}-3$ substituent exhibit less contacts in the selectivity pocket (Figure SF7). However, docking scores of active and inactive analogues did not show a significant difference (data not shown) and could not be used to justify the different inhibitory activity of analogues with differing N-3 substituents. This is a well-recognized limitation of scoring functions used in molecular docking, especially due to the complexity derived from desolvation effects. ${ }^{85-88}$ Interestingly, docking of biphenyl-3yl analogues (Table 1, column i) suggests that the biphenyl ring can also be accommodated inside the selectivity pocket in a manner similar to that in the naphthyl ring of 29c maintaining the $\pi-\pi /$ hydrophobic contacts, even though both groups differ in their overall shape (Figure SF9, Supporting Information).

The groove occupied by the DMI moiety of $29 \mathrm{c}$ is wide and mostly lined by hydrophobic residues such as Phe96, Phe119, Phe234, and Phe235. This explains why a wide variety of $\mathrm{N}-7^{\prime}$ substituents are well-tolerated at the $\mathrm{N}-7^{\prime}$ end of the 
Table 3. SIRT Isoform Selectivity Data for Selected Compounds ${ }^{a}$

\begin{tabular}{|c|c|c|c|c|c|}
\hline \multirow[b]{2}{*}{ compd } & \multicolumn{3}{|c|}{$\mathrm{IC}_{50}(\mu \mathrm{M})$} & \multirow[b]{2}{*}{ SIRT2/SIRT1 selectivity } & \multirow[b]{2}{*}{ SIRT2/SIRT3 selectivity } \\
\hline & Sirt2 & SIRT1 & SIRT3 & & \\
\hline $15 e$ & $0.39 \pm 0.02$ & $42.12 \pm 15.91$ & $>100$ & 108 & $>256$ \\
\hline $18 \mathrm{a}$ & $0.65 \pm 0.03$ & $119.4 \pm 28.15$ & $177.4 \pm 4.17$ & 185 & 275 \\
\hline $19 a^{b}$ & $1.45 \pm 0.1$ & $>100$ & $>100$ & $>100$ & $>100$ \\
\hline $29 \mathrm{c}$ & $0.58 \pm 0.02$ & $129 \pm 16.97$ & $17.99 \pm 2.45$ & 222 & 31 \\
\hline $41 c$ & $0.73 \pm 0.19$ & $13.83 \pm 1.57$ & $11.19 \pm 0.74$ & 19 & 15 \\
\hline
\end{tabular}

thienopyrimidinone core (Table 1). SAR analysis for this series (ring-opened vs ring closed cyclohexyl fused core ring) and our previous SIRT2 inhibitor enantiomer data ${ }^{81}$ suggest that the configuration of the chiral center at position 7 does not have a substantial effect on SIRT2 inhibitory activity; however, electron density for only the $R$-isomer of $29 \mathrm{c}$ (R-29c) was observed in the SIRT2 binding pocket, despite using the racemate for crystallization. Docking suggests that the $S$-isomer of 29c (S-29c) retains a similar binding mode inside the SIRT2 pocket (Figure SF10, Supporting Information) albeit with a slightly lower docking score $(-13.13 \mathrm{kcal} / \mathrm{mol}$ for $R-29 \mathrm{c}$ vs $-12.17 \mathrm{kcal} / \mathrm{mol}$ for S-29c). Similar docking results were obtained for other potent analogues (Table ST1, Supporting Information) suggesting that the SIRT2 pocket can accommodate either isomer with slight preference for the $R$ configuration.

Overall, these studies suggest that the reported analogues induce a selectivity pocket in the active site of SIRT2 in a similar fashion to the previously reported aminothiazole derivatives (such as 8), albeit in an inverted fashion, and that the overall binding is driven by the $\pi-\pi$ and hydrophobic forces.

Since our thienopyrimidinone analogues share the same SIRT2 pocket as $\mathbf{8}$ and interact similarly and principally via hydrophobic forces, we considered whether the activity of the aminothiazole series ( $\mathrm{cf} 8$ ) might also have some dependence on the lipophilicity of this series. It is interesting that all highly active analogues (SIRT2 $\mathrm{IC}_{50}<5 \mu \mathrm{M}$ ) of this previously reported series $^{79}$ lie in a range of cLogP $4-6$ and possess 3-4 aromatic rings, whereas inactive analogues (exhibiting SIRT2 inhibition only at $50 \mu \mathrm{M})$ are distributed between a wider range of cLogP 3-7 (Figure SF11, Supporting Information). It should be noted, however, that any observed lack of activity may also be due to the missing essential pharmacophore features, such as the DMP ring, as reported earlier for this series. ${ }^{77-79}$ We observed high correlation $(r=0.865$, Figure SF12, Supporting Information) between $\mathrm{IC}_{50}$ and $\mathrm{cLogP}$ values for the highly active analogues $\left(\mathrm{IC}_{50}<5 \mu \mathrm{M}\right)$ in this series, which possess the key pharmacophore requirements. Together with the cLogP based analysis of our series, these observations suggest an optimum lipophilicity is required by ligands to bind in this SIRT2 pocket and probably to induce the selectivity pocket. This information can be used in the future for the further optimization of both SIRT2 inhibitor series.

Selectivity Study. In our previous study, ${ }^{81}$ we found 19 a to be more than 100 times more selective for SIRT2 in comparison to SIRT1, SIRT3, and SIRT5. To further evaluate the subtype selectivity of this series, we evaluated the most potent SIRT2 inhibitory compounds against SIRT1 and SIRT3 (Table 3). All assays used the same fluorogenic peptide substrate derived from p53 (see Experimental Section), and full $(10-)$ dose-response SIRT2 $\mathrm{IC}_{50}$ values $(n=2)$ were calculated. Suramin was used as a positive control for SIRT1 and SIRT2, and nicotinamide was used for SIRT3. All controls gave similar inhibitory activity to that observed previously.
A vehicle (DMSO) was used as the negative control. To our delight, 15e and 18a maintained excellent SIRT2 selectivity (>100 fold) over SIRT1 and SIRT3. In contrast, compound 29c maintained good selectivity for SIRT2 over SIRT1 (>200 fold) but exhibits comparably poorer selectivity against SIRT3 ( $\sim 30$ fold). Analogue 41c was found to be the least selective, with only 19- and 15-fold selectivity for SIRT2 vs SIRT1 and SIRT3, respectively. Therefore, it would seem that this series generally maintains excellent selectivity for SIRT2, except when a 4-methoxy-naphthalen-1-yl group is present in the N-3 position. Notably, N-3-substituents are mainly responsible for inducing the selectivity pocket that presumably imparts the isoform selectivity. Interestingly, we could not find any relevant differences between the sequences of SIRT1-3 in the selectivity pocket and the other enzyme parts contacting the ligand, which would rationalize the precise inhibitor selectivities observed. However, comparison of our SIRT2-29c complex to the structures of SIRT1 and SIRT3 reveals that the selectivity pocket of the latter two is different from that of SIRT2 due to notably different conformations of residues 130-143 (SIRT2 numbering), which form helix $\alpha 6$ and the consecutive loop (Figure SF13, Supporting Information). The isoform specificity thus appears to be caused indirectly by more distant isoenzyme features that influence the conformation of this sirtuin region.

Tubulin Hyperacetylation. To demonstrate the cellular activity of this series, we studied the effect of active analogues to result in hyperacetylation of $\alpha$-tubulin, a well-known SIRT2 substrate. $^{89}$ The MCF-7 breast epithelial cancer cell line was treated with different concentrations of 29c. Our previously published SIRT2 inhibitor from this series $19 a^{81}$ and $6,{ }^{62}$ a different SIRT inhibitor chemotype, were used as positive controls. Additionally, analogue $\mathbf{2 5}$ g lacking in vitro activity against SIRT2 (Table 1) was used as a negative control. To rule out the possibility of increased acetylation of $\alpha$-tubulin due to histone deacetylase activity by metallo-HDACs (particularly HDAC6), trichostatin, ${ }^{90}$ a pan HDAC inhibitor with no effect on SIRT2 activity, was employed in the experiments. Treatment of cells with 29c resulted in increased levels of $\alpha$-tubulin acetylation in a dose dependent manner (Figure 4a). In contrast, no effect on tubulin acetylation levels was observed with $\mathbf{2 5 g}$ (Figure $4 \mathrm{~b}$ ) confirming that the enzymatic SIRT2 inhibition data obtained for our series correlates to $\alpha$-tubulin hyperacetylation. For prior inhibitors 19a and 6, tubulin hyperacetylation was only observed at a treatment concentration of $20 \mu \mathrm{M}$ or higher (Figure $4 \mathrm{c}, \mathrm{d}$ ), under the given conditions. While this might be due to the slightly improved SIRT2 inhibitory potency of $29 \mathrm{c}\left(\mathrm{IC}_{50}=0.58 \mu \mathrm{M}\right)$ over $19 \mathrm{a}\left(\mathrm{IC}_{50}=\right.$ $1.45 \mu \mathrm{M})$, clearly other physiochemical and stability differences between these two inhibitors will result in a difference in the observed cell potency. 

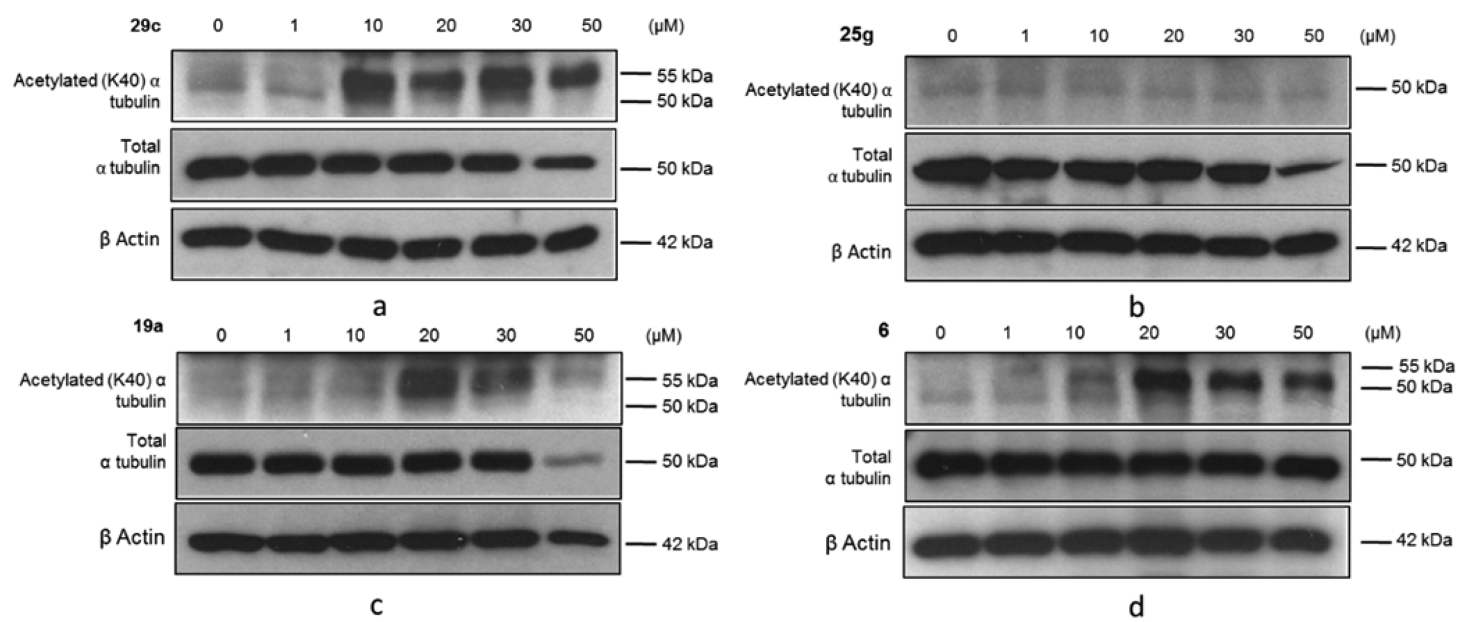

Figure 4. Effect of SIRT2 inhibitors on tubulin acetylation. MCF-7 cell lines were treated with inhibitors at the doses stated for $24 \mathrm{~h}$ in the presence of trichostatin A (TSA) (50 nM). TSA was added to ensure the inhibition of the non-sirtuin histone deacetylase activity. Protein samples were analyzed by Western blotting using antibodies against acetylated (lysine-40) $\alpha$-tubulin, total $\alpha$-tubulin, and $\beta$-actin. $\beta$-Actin was probed as a control for protein loading. (a) Compound 29c increased the $\alpha$-tubulin acetylation level at $10 \mu \mathrm{M}$ and retained consistent to $50 \mu \mathrm{M}$. (b) Compound 25g, as a negative control, showed no effect on the acetylation of $\alpha$-tubulin. (c) Compound 19a showed increased acetylated $\alpha$-tubulin level at $20 \mu \mathrm{M}$ and decreased level at $50 \mu \mathrm{M}$. (d) 6 as a positive control showed significant increase of $\alpha$-tubulin acetylation at 10 to $50 \mu \mathrm{M}$. $N=3$.

\section{CONCLUSION}

In conclusion, we have conducted an extensive SAR study of our previously reported thienopyrimidinone SIRT2 inhibitor series and identified a number of inhibitors with submicromolar SIRT2 activity, while retaining good to excellent selectivity over the other SIRT isoforms tested. Our SAR analysis has revealed that a reasonably large variety of substituents can be tolerated at the $\mathrm{N}-7^{\prime}$-position, while a larger lipophilic bicyclic/biphenyl ring is preferred at the N-3 position. An X-ray crystal structure of SIRT2 in complex with analogue $29 \mathrm{c}$ revealed that our series of compounds also result in the induction of a previously described $^{77-79}$ selectivity pocket in the SIRT2 active site. This ligand induced selectivity pocket likely explains the high selectivity of the tested analogues for SIRT2 over other subtypes of the SIRT enzyme. Notably, our study adds to the growing examples of ligand induced SIRT2 conformational change ${ }^{77-80}$ and hence cautions against the reliability of molecular docking methods for binding site and orientation prediction of SIRT2 inhibitors, using static structures. Consistent with the hydrophobic nature of the selectivity pocket and the surrounding groove, we have found that active analogues in both thienopyrimidinone and aminothiazole series (such as 8) possess cLogP within an optimum range. This finding should be useful for further inhibitor optimization since a simple to calculate descriptor like cLogP can be employed in compound design and decision making.

\section{EXPERIMENTAL SECTION}

Chemistry. All chemicals and reagents were acquired from commercial sources and used as such unless specified otherwise. All reactions were performed under an atmosphere of dry nitrogen unless otherwise stated. Flash column chromatography was carried out using Merck Kiesegel 60 silica gel (230-400 mesh, $0.0400 .063 \mathrm{~mm}$ ). Thin layer chromatography (TLC) was performed on aluminum plates using Merck Kiesegel 60 F254 (230-400 mesh) fluorescent treated silica which were visualized under ultraviolet light $(254 \mathrm{~nm})$ or by staining with potassium permanganate or ninhydrin solution as appropriate. Chemical shifts $(\delta)$ are quoted in units of parts per million (ppm) referenced with the appropriate internal standard (TMS: $\delta=0 \mathrm{ppm}$ ). Coupling constants $(J)$ are given in Hertz $(\mathrm{Hz})$. The ${ }^{1} \mathrm{H}$ NMR spectra of representative compounds are reported as follows: ppm (multiplicity, coupling constants $\mathrm{J} / \mathrm{Hz}$, number of protons). Synthetic schemes for the synthesis of analogues in Table 1 and Table 2 are given in the Supporting Information. Purities of all the assayed compounds were determined by LCMS methods (described in Supporting Information) and were found to have $\geq 95 \%$ purity, except those specified in Table ST2.

7-((3-Fluorobenzyl)amino)-3-(naphthalen-1-ylmethyl)-5,6,7,8tetrahydrobenzo $[4,5]$ thieno $[2,3-d]$ pyrimidin-4(3H)-one (10b). ${ }^{1} \mathrm{H}$ NMR (400 MHz, DMSO- $\left.d_{6}\right) \delta 8.43(\mathrm{~s}, 1 \mathrm{H}), 8.19$ (d, $J=$ $8.2 \mathrm{~Hz}, 1 \mathrm{H}), 7.99(\mathrm{~d}, J=7.9 \mathrm{~Hz}, 1 \mathrm{H}), 7.89(\mathrm{~d}, J=8.3 \mathrm{~Hz}, 1 \mathrm{H}), 7.61$ $(\mathrm{dt}, J=17.8,7.0 \mathrm{~Hz}, 2 \mathrm{H}), 7.45(\mathrm{t}, J=7.7 \mathrm{~Hz}, 1 \mathrm{H}), 7.34(\mathrm{q}, J=7.5 \mathrm{~Hz}$, $1 \mathrm{H}), 7.25-7.16(\mathrm{~m}, 2 \mathrm{H}), 7.10-6.98(\mathrm{~m}, 2 \mathrm{H}), 5.68(\mathrm{~s}, 2 \mathrm{H}), 3.82(\mathrm{~s}$, $2 \mathrm{H}), 3.13-3.00(\mathrm{~m}, 2 \mathrm{H}), 2.94(\mathrm{~s}, 1 \mathrm{H}), 2.85-2.72(\mathrm{~m}, 1 \mathrm{H}), 2.58(\mathrm{dd}$, $J=16.5,7.8 \mathrm{~Hz}, 1 \mathrm{H}), 2.03-1.95(\mathrm{~m}, 1 \mathrm{H}), 1.67-1.58(\mathrm{~m}, 1 \mathrm{H})$.

7-((3-Fluorobenzyl)amino)-3-(naphthalen-2-ylmethyl)-5,6,7,8tetrahydrobenzo[4,5]thieno[2,3-d]pyrimidin-4(3H)-one (10d). ${ }^{1} \mathrm{H}$ NMR $\left(400 \mathrm{MHz}\right.$, DMSO- $\left.d_{6}\right) \delta 8.60(\mathrm{~s}, 1 \mathrm{H}), 7.91-7.88(\mathrm{~m}, 2 \mathrm{H})$, $7.81(\mathrm{~d}, J=1.7 \mathrm{~Hz}, 1 \mathrm{H}), 7.58-7.43(\mathrm{~m}, 3 \mathrm{H}), 7.33(\mathrm{td}, J=7.9,6.1 \mathrm{~Hz}$, $1 \mathrm{H}), 7.22-7.18(\mathrm{~m}, 2 \mathrm{H}), 7.06-7.00(\mathrm{~m}, 1 \mathrm{H}), 5.33(\mathrm{~s}, 2 \mathrm{H}), 3.81(\mathrm{~s}$, $2 \mathrm{H}), 3.10-2.98(\mathrm{~m}, 2 \mathrm{H}), 2.95-2.88(\mathrm{~m}, 1 \mathrm{H}), 2.79-2.70(\mathrm{~m}, 1 \mathrm{H})$, $2.59-2.53(\mathrm{~m}, 1 \mathrm{H}), 2.00-1.94(\mathrm{~m}, 1 \mathrm{H}), 1.65-1.56(\mathrm{~m}, 1 \mathrm{H})$.

7-((2-Fluorobenzyl)amino)-3-(naphthalen-1-ylmethyl)-5,6,7,8tetrahydrobenzo[4,5]thieno[2,3-d]pyrimidin-4(3H)-one (11b). ${ }^{1} \mathrm{H}$ NMR $\left(400 \mathrm{MHz}\right.$, DMSO- $\left.d_{6}\right) \delta 8.43(\mathrm{~s}, 1 \mathrm{H}), 8.19(\mathrm{~d}, J=8.3 \mathrm{~Hz}$, $1 \mathrm{H}), 7.99(\mathrm{~d}, J=7.8 \mathrm{~Hz}, 1 \mathrm{H}), 7.89(\mathrm{~d}, J=8.2 \mathrm{~Hz}, 1 \mathrm{H}), 7.66-7.57(\mathrm{~m}$, $2 \mathrm{H}), 7.52-7.43(\mathrm{~m}, 2 \mathrm{H}), 7.31-7.25(\mathrm{~m}, 1 \mathrm{H}), 7.18-7.12(\mathrm{~m}, 2 \mathrm{H})$, $7.07(\mathrm{~d}, J=7.1 \mathrm{~Hz}, 1 \mathrm{H}), 5.68(\mathrm{~s}, 2 \mathrm{H}), 3.84(\mathrm{~s}, 2 \mathrm{H}), 3.07(\mathrm{dd}, J=16.6$, $5.4 \mathrm{~Hz}, 2 \mathrm{H}), 2.99-2.94(\mathrm{~m}, 1 \mathrm{H}), 2.83-2.75(\mathrm{~m}, 1 \mathrm{H}), 2.59(\mathrm{dd}, J=$ $16.5,7.7 \mathrm{~Hz}, 1 \mathrm{H}), 2.02-1.99(\mathrm{~m}, 1 \mathrm{H}), 1.64(\mathrm{dtd}, J=14.3,9.1$, $5.4 \mathrm{~Hz}, 1 \mathrm{H})$.

7-((4-Chlorobenzyl)amino)-3-(naphthalen-2-ylmethyl)-5,6,7,8tetrahydrobenzo[4,5]thieno[2,3-d]pyrimidin-4(3H)-one (13b). ${ }^{1} \mathrm{H}$ NMR $\left(400 \mathrm{MHz}\right.$, DMSO- $\left.d_{6}\right) \delta 8.60(\mathrm{~s}, 1 \mathrm{H}), 7.91-7.88(\mathrm{~m}, 3 \mathrm{H})$, $7.81(\mathrm{~s}, 1 \mathrm{H}), 7.53-7.49(\mathrm{~m}, 3 \mathrm{H}), 7.39-7.33(\mathrm{~m}, 4 \mathrm{H}), 5.33(\mathrm{~s}, 2 \mathrm{H})$, $3.77(\mathrm{~s}, 2 \mathrm{H}), 3.07-2.99(\mathrm{~m}, 2 \mathrm{H}), 2.91-2.89(\mathrm{~m}, 1 \mathrm{H}), 2.79-2.71(\mathrm{~m}$, $1 \mathrm{H}), 2.58-2.52(\mathrm{~m}, 1 \mathrm{H}), 2.00-1.95(\mathrm{~m}, 1 \mathrm{H}), 1.59(\mathrm{dtd}, J=14.0,8.9$, $8.5,5.2 \mathrm{~Hz}, 1 \mathrm{H})$.

4-(((3-(Naphthalen-2-ylmethyl)-4-oxo-3,4,5,6, 7, 8hexahydrobenzo[4,5]thieno[2,3-d]pyrimidin-7-yl)amino)methyl)benzonitrile (15d). ${ }^{1} \mathrm{H}$ NMR $\left(400 \mathrm{MHz}, \mathrm{DMSO}-d_{6}\right) \delta 8.60(\mathrm{~s}, 1 \mathrm{H})$, $7.96-7.85(\mathrm{~m}, 3 \mathrm{H}), 7.81(\mathrm{~d}, J=1.6 \mathrm{~Hz}, 1 \mathrm{H}), 7.80-7.71(\mathrm{~m}, 2 \mathrm{H}), 7.56$ $(\mathrm{d}, J=8.0 \mathrm{~Hz}, 2 \mathrm{H}), 7.55-7.43(\mathrm{~m}, 3 \mathrm{H}), 5.33(\mathrm{~s}, 2 \mathrm{H}), 3.87(\mathrm{~s}, 2 \mathrm{H})$, $3.10-2.96(\mathrm{~m}, 2 \mathrm{H}), 2.93-2.87(\mathrm{~m}, 1 \mathrm{H}), 2.79-2.71(\mathrm{~m}, 1 \mathrm{H}), 2.581-$ $2.51(\mathrm{~m}, 1 \mathrm{H}), 2.00-1.94(\mathrm{~m}, 1 \mathrm{H}), 1.65-1.55(\mathrm{~m}, 1 \mathrm{H})$. 
4-(((4-Oxo-3-(quinolin-8-ylmethyl)-3,4,5,6,7,8-hexahydrobenzo[4,5]thieno[2,3-d]pyrimidin-7-yl)amino)methyl)benzonitrile (15e). ${ }^{1} \mathrm{H}$ NMR (400 MHz, DMSO-d $\left.d_{6}\right) \delta 9.00(\mathrm{dd}, J=4.2,1.8 \mathrm{~Hz}, 1 \mathrm{H})$, $8.65(\mathrm{~s}, 1 \mathrm{H}), 8.43(\mathrm{dd}, J=8.4,1.8 \mathrm{~Hz}, 1 \mathrm{H}), 7.95(\mathrm{~d}, J=8.1 \mathrm{~Hz}, 1 \mathrm{H})$, $7.76(\mathrm{~d}, J=7.9 \mathrm{~Hz}, 2 \mathrm{H}), 7.62(\mathrm{dd}, J=8.3,4.2 \mathrm{~Hz}, 1 \mathrm{H}), 7.58-7.54(\mathrm{~m}$, $3 \mathrm{H}), 7.45(\mathrm{~d}, J=7.0 \mathrm{~Hz}, 1 \mathrm{H}), 5.76(\mathrm{~s}, 2 \mathrm{H}), 3.87(\mathrm{~s}, 2 \mathrm{H}), 3.07-3.00$ (m, 2H), 2.93-2.87 (m, 1H), $2.73(\mathrm{dt}, J=16.8,7.4 \mathrm{~Hz}, 1 \mathrm{H}), 2.58-$ $2.54(\mathrm{~m}, 1 \mathrm{H}), 2.00-1.95(\mathrm{~m}, 1 \mathrm{H}), 1.65-1.55(\mathrm{~m}, 1 \mathrm{H})$.

7-((Pyridin-3-ylmethyl)amino)-3-(quinolin-8-ylmethyl)-5,6,7,8tetrahydrobenzo[4,5]thieno[2,3-d]pyrimidin-4(3H)-one $(19 e) .{ }^{1} \mathrm{H}$ NMR $\left(400 \mathrm{MHz}\right.$, DMSO- $\left.d_{6}\right) \delta 9.00(\mathrm{dd}, J=4.4,1.7 \mathrm{~Hz}, 1 \mathrm{H}), 8.65$ $(\mathrm{s}, 1 \mathrm{H}), 8.54(\mathrm{~d}, J=2.2 \mathrm{~Hz}, 1 \mathrm{H}), 8.50-8.32(\mathrm{~m}, 2 \mathrm{H}), 8.21(\mathrm{~s}, 1 \mathrm{H})$, $7.95(\mathrm{~d}, J=8.1 \mathrm{~Hz}, 1 \mathrm{H}), 7.76(\mathrm{~d}, J=7.7 \mathrm{~Hz}, 1 \mathrm{H}), 7.62(\mathrm{dd}, J=8.3,4.2$ $\mathrm{Hz}, 1 \mathrm{H}), 7.56(\mathrm{t}, J=7.6 \mathrm{~Hz}, 1 \mathrm{H}), 7.45(\mathrm{~d}, J=7.2 \mathrm{~Hz}, 1 \mathrm{H}), 7.32(\mathrm{dd}$, $J=7.8,4.7 \mathrm{~Hz}, 1 \mathrm{H}), 5.76(\mathrm{~s}, 2 \mathrm{H}), 3.81(\mathrm{~s}, 2 \mathrm{H}), 3.05(\mathrm{dd}, J=16.5$, $4.8 \mathrm{~Hz}, 2 \mathrm{H}), 2.95-2.90(\mathrm{~m}, 1 \mathrm{H}), 2.74(\mathrm{dt}, J=16.6,7.9 \mathrm{~Hz}, 1 \mathrm{H})$, $2.59-2.53(\mathrm{~m}, 1 \mathrm{H}), 2.02-1.95(\mathrm{~m}, 1 \mathrm{H}), 1.65-1.56(\mathrm{~m}, 1 \mathrm{H})$.

7-((Pyrimidin-5-ylmethyl)amino)-3-(quinolin-8-ylmethyl)-5,6,7,8tetrahydrobenzo[4,5]thieno[2,3-d]pyrimidin-4(3H)-one $(22 e) .{ }^{1} \mathrm{H}$ NMR $\left(400 \mathrm{MHz}\right.$, DMSO- $\left.d_{6}\right) \delta 9.05(\mathrm{~s}, 1 \mathrm{H}), 9.00(\mathrm{dd}, J=4.2,1.8$ $\mathrm{Hz}, 1 \mathrm{H}), 8.76(\mathrm{~s}, 2 \mathrm{H}), 8.65(\mathrm{~s}, 1 \mathrm{H}), 8.42(\mathrm{dd}, J=8.2,1.7 \mathrm{~Hz}, 1 \mathrm{H})$, $8.24(\mathrm{~s}, 1 \mathrm{H}), 7.95(\mathrm{~d}, J=8.1 \mathrm{~Hz}, 1 \mathrm{H}), 7.62(\mathrm{dd}, J=8.2,4.2 \mathrm{~Hz}, 1 \mathrm{H})$, $7.56(\mathrm{t}, J=7.7 \mathrm{~Hz}, 1 \mathrm{H}), 7.45(\mathrm{~d}, J=7.2 \mathrm{~Hz}, 1 \mathrm{H}), 5.76(\mathrm{~s}, 2 \mathrm{H}), 3.82$ $(\mathrm{s}, 2 \mathrm{H}), 3.08-3.01(\mathrm{~m}, 2 \mathrm{H}), 2.96-2.92(\mathrm{~m}, 1 \mathrm{H}), 2.75(\mathrm{dt}, J=16.7$, $6.9 \mathrm{~Hz}, 1 \mathrm{H}), 2.59-2.54(\mathrm{~m}, 1 \mathrm{H}), 2.00-1.96(\mathrm{~m}, 1 \mathrm{H}), 1.65-1.56$ $(\mathrm{m}, 1 \mathrm{H})$.

3-(Naphthalen-2-ylmethyl)-7-((tetrahydrofuran-3-yl)methyl)amino)-5,6,7,8-tetrahydrobenzo[4,5]thieno[2,3-d]pyrimidin-4(3H)one (26d). ${ }^{1} \mathrm{H}$ NMR $\left(400 \mathrm{MHz}, \mathrm{DMSO}-d_{6}\right) \delta 8.59(\mathrm{~s}, 1 \mathrm{H}), 7.98-7.85$ $(\mathrm{m}, 2 \mathrm{H}), 7.81(\mathrm{~s}, 1 \mathrm{H}), 7.50(\mathrm{~d}, J=7.9 \mathrm{~Hz}, 3 \mathrm{H}), 5.33(\mathrm{~s}, 2 \mathrm{H}), 3.69(\mathrm{dt}$, $J=13.7,7.7 \mathrm{~Hz}, 2 \mathrm{H}), 3.58(\mathrm{q}, J=7.5 \mathrm{~Hz}, 1 \mathrm{H}), 3.39-3.31(\mathrm{~m}, 2 \mathrm{H})$, $3.11-2.95(\mathrm{~m}, 2 \mathrm{H}), 2.90(\mathrm{~s}, 1 \mathrm{H}), 2.82-2.68(\mathrm{~m}, 1 \mathrm{H}), 2.62-2.57(\mathrm{~m}$, $2 \mathrm{H}), 2.36-2.17(\mathrm{~m}, 1 \mathrm{H}), 2.03-1.84(\mathrm{~m}, 2 \mathrm{H}), 1.62-1.40(\mathrm{~m}, 2 \mathrm{H})$.

7-(((3,5-Dimethylisoxazol-4-yl)methyl)amino)-3-((2-methoxynaphthalen-1-yl)methyl)-5,6,7,8-tetrahydrobenzo[4,5] thieno[2,3d]pyrimidin-4(3H)-one (29a). ${ }^{1} \mathrm{H}$ NMR (400 MHz, DMSO- $d_{6}$ ) $\delta 8.21-8.18(\mathrm{~m}, 1 \mathrm{H}), 8.05-8.02(\mathrm{~m}, 2 \mathrm{H}), 7.91(\mathrm{~d}, J=8.1 \mathrm{~Hz}, 1 \mathrm{H})$, 7.55-7.52 (m, 2H), $7.39(\mathrm{t}, J=7.5 \mathrm{~Hz}, 1 \mathrm{H}), 5.55(\mathrm{~s}, 2 \mathrm{H}), 3.98(\mathrm{~s}$, $3 \mathrm{H}), 3.52(\mathrm{~s}, 2 \mathrm{H}), 3.12-2.99(\mathrm{~m}, 2 \mathrm{H}), 2.92-2.87(\mathrm{~m}, 1 \mathrm{H}), 2.84-2.76$ (m, 1H), 2.55-2.52 (m, 1H), $2.32(\mathrm{~s}, 3 \mathrm{H}), 2.17(\mathrm{~s}, 3 \mathrm{H}), 2.01-1.98$ (m, 1H), 1.62-1.51 (m, 1H).

3-(Naphthalen-1-ylmethyl)-7-((thiophen-2-ylmethyl)amino)5,6,7,8-tetrahydrobenzo[4,5]thieno[2,3-d]pyrimidin-4(3H)-one (30b). ${ }^{1} \mathrm{H}$ NMR $\left(400 \mathrm{MHz}, \mathrm{DMSO}-d_{6}\right) \delta 8.43(\mathrm{~s}, 1 \mathrm{H}), 8.19(\mathrm{~d}, J=$ $8.3 \mathrm{~Hz}, 1 \mathrm{H}), 7.99$ (d, $J=8.0 \mathrm{~Hz}, 1 \mathrm{H}), 7.89$ (d, $J=8.3 \mathrm{~Hz}, 1 \mathrm{H}), 7.66-$ $7.57(\mathrm{~m}, 2 \mathrm{H}), 7.45(\mathrm{t}, J=7.7 \mathrm{~Hz}, 1 \mathrm{H}), 7.36(\mathrm{~d}, J=5.1 \mathrm{~Hz}, 1 \mathrm{H}), 7.07$ $(\mathrm{d}, J=7.1 \mathrm{~Hz}, 1 \mathrm{H}), 6.98-6.94(\mathrm{~m}, 2 \mathrm{H}), 5.68(\mathrm{~s}, 2 \mathrm{H}), 4.00(\mathrm{~s}, 2 \mathrm{H})$, $3.11-2.96(\mathrm{~m}, 3 \mathrm{H}), 2.78(\mathrm{dt}, J=16.9,7.3 \mathrm{~Hz}, 1 \mathrm{H}), 2.58(\mathrm{dd}, J=16.3$, $7.6 \mathrm{~Hz}, 1 \mathrm{H}), 2.06-1.93(\mathrm{~m}, 1 \mathrm{H}), 1.67-1.58(\mathrm{~m}, 1 \mathrm{H})$.

3-(Naphthalen-2-ylmethyl)-7-((thiophen-2-ylmethyl)amino)5,6,7,8-tetrahydrobenzo[4,5]thieno[2,3-d]pyrimidin-4(3H)-one (30d). ${ }^{1} \mathrm{H}$ NMR (400 MHz, DMSO-d $\left.d_{6}\right) \delta 8.59(\mathrm{~s}, 1 \mathrm{H}), 7.91-7.88$ $(\mathrm{m}, 3 \mathrm{H}), 7.81(\mathrm{~s}, 1 \mathrm{H}), 7.58-7.44(\mathrm{~m}, 3 \mathrm{H}), 7.35(\mathrm{dd}, J=5.0,1.3 \mathrm{~Hz}$, $1 \mathrm{H}), 6.97-6.93(\mathrm{~m}, 2 \mathrm{H}), 5.33(\mathrm{~s}, 2 \mathrm{H}), 3.98(\mathrm{~s}, 2 \mathrm{H}), 3.08-2.96(\mathrm{~m}$, $3 \mathrm{H}), 2.79-2.71,2.58-2.54(\mathrm{~m}, 1 \mathrm{H}), 2.00-1.96(\mathrm{~m}, 1 \mathrm{H}), 1.63-1.54$ $(\mathrm{m}, 1 \mathrm{H})$.

3-(Quinolin-8-ylmethyl)-7-((thiophen-2-ylmethyl)amino)-5,6,7,8tetrahydrobenzo[4,5]thieno[2,3-d]pyrimidin-4(3H)-one $(30 e) .{ }^{1} \mathrm{H}$ NMR (400 MHz, DMSO- $\left.d_{6}\right) \delta 9.01(\mathrm{~d}, J=3.8 \mathrm{~Hz}, 1 \mathrm{H}), 8.65(\mathrm{~s}$, $1 \mathrm{H}), 8.43(\mathrm{~d}, J=8.3 \mathrm{~Hz}, 1 \mathrm{H}), 8.16(\mathrm{~s}, 1 \mathrm{H}), 7.95(\mathrm{~d}, J=8.1 \mathrm{~Hz}, 1 \mathrm{H})$, $7.62(\mathrm{dd}, J=8.3,4.2 \mathrm{~Hz}, 1 \mathrm{H}), 7.56(\mathrm{t}, J=7.7 \mathrm{~Hz}, 1 \mathrm{H}), 7.44(\mathrm{~d}, J=$ $7.2 \mathrm{~Hz}, 1 \mathrm{H}), 7.36(\mathrm{~d}, J=5.0 \mathrm{~Hz}, 1 \mathrm{H}), 6.98-6.93(\mathrm{~m}, 2 \mathrm{H}), 5.76(\mathrm{~s}$, $2 \mathrm{H}), 3.98(\mathrm{~s}, 2 \mathrm{H}), 3.06-2.97(\mathrm{~m}, 3 \mathrm{H}), 2.75-2.68(\mathrm{~m}, 1 \mathrm{H}), 2.58-2.56$ (m, 1H), 1.99-1.95 (m, 1H), 1.66-1.54 (m, 1H).

3-([1, 1'-Biphenyl]-3-ylmethyl)-7-((thiophen-2-ylmethyl)amino)5,6,7,8-tetrahydrobenzo[4,5]thieno[2,3-d]pyrimidin-4(3H)-one (30i). ${ }^{1} \mathrm{H}$ NMR (400 MHz, DMSO- $\left.d_{6}\right) \delta 8.60(\mathrm{~s}, 1 \mathrm{H}), 7.68(\mathrm{~s}, 1 \mathrm{H})$, $7.63(\mathrm{~d}, J=7.6 \mathrm{~Hz}, 2 \mathrm{H}), 7.58(\mathrm{~d}, J=7.9 \mathrm{~Hz}, 1 \mathrm{H}), 7.51-7.35(\mathrm{~m}, 4 \mathrm{H})$, $7.39-7.28(\mathrm{~m}, 2 \mathrm{H}), 7.00-6.90(\mathrm{~m}, 2 \mathrm{H}), 5.22(\mathrm{~s}, 2 \mathrm{H}), 3.97(\mathrm{~s}, 2 \mathrm{H})$, 3.11-2.94 (s, 3H), 2.80-2.71 (m, $1 \mathrm{H}), 2.59-2.50(\mathrm{~m}, 1 \mathrm{H}), 2.02-$ $1.93(\mathrm{~m}, 1 \mathrm{H}), 1.66-1.51(\mathrm{~m}, 1 \mathrm{H})$.
3-((4-Methoxynaphthalen-1-yl)methyl)-7-((2-methoxyphenethyl) amino)-5,6,7,8-tetrahydrobenzo[4,5] thieno[2,3-d]pyrimidin-4(3H)one (33c). ${ }^{1} \mathrm{H}$ NMR (400 MHz, DMSO- $\left.d_{6}\right) \delta 8.36(\mathrm{~s}, 1 \mathrm{H}), 8.22(\mathrm{~d}$, $J=9.1 \mathrm{~Hz}, 2 \mathrm{H}), 8.12(\mathrm{~d}, J=8.4 \mathrm{~Hz}, 1 \mathrm{H}), 7.63(\mathrm{t}, J=7.4 \mathrm{~Hz}, 1 \mathrm{H}), 7.56$ $(\mathrm{t}, J=7.6 \mathrm{~Hz}, 1 \mathrm{H}), 7.20-7.15(\mathrm{~m}, 3 \mathrm{H}), 6.94(\mathrm{dd}, J=8.1,3.2 \mathrm{~Hz}, 2 \mathrm{H})$, $6.86(\mathrm{t}, J=7.4 \mathrm{~Hz}, 1 \mathrm{H}), 5.57(\mathrm{~s}, 2 \mathrm{H}), 3.95(\mathrm{~s}, 3 \mathrm{H}), 3.77(\mathrm{~s}, 3 \mathrm{H}), 3.11-$ $3.03(\mathrm{~m}, 3 \mathrm{H}), 2.85-2.77(\mathrm{~m}, 3 \mathrm{H}), 2.73(\mathrm{t}, J=7.7 \mathrm{~Hz}, 2 \mathrm{H}), 2.61-2.55$ $(\mathrm{m}, 1 \mathrm{H}), 2.03-1.98(\mathrm{~m}, 1 \mathrm{H}), 1.65-1.56(\mathrm{~m}, 1 \mathrm{H})$.

7-((2-Cyclohexylethyl)amino)-3-(naphthalen-2-ylmethyl)-5,6,7,8tetrahydrobenzo[4,5]thieno[2,3-d]pyrimidin-4(3H)-one $(34 d) .{ }^{1} \mathrm{H}$ NMR $\left(400 \mathrm{MHz}\right.$, DMSO- $\left.d_{6}\right) \delta 8.62(\mathrm{~s}, 1 \mathrm{H}), 7.91-7.85(\mathrm{~m}, 3 \mathrm{H})$, $7.81(\mathrm{~s}, 1 \mathrm{H}), 7.52-7.49(\mathrm{~m}, 3 \mathrm{H}), 5.33(\mathrm{~s}, 2 \mathrm{H}), 3.12-3.07(\mathrm{~m}, 3 \mathrm{H})$, $2.80-2.74(\mathrm{~m}, 3 \mathrm{H}), 2.69-2.55(\mathrm{~m}, 1 \mathrm{H}), 2.04(\mathrm{t}, J=9.4 \mathrm{~Hz}, 1 \mathrm{H})$, $1.68-1.59(\mathrm{~m}, 5 \mathrm{H}), 1.38-1.28(\mathrm{~m}, 3 \mathrm{H}), 1.23-1.10(\mathrm{~m}, 3 \mathrm{H}), 0.92-$ $0.84(\mathrm{~m}, 2 \mathrm{H})$

7-((2-Methoxyphenyl)amino)-3-(naphthalen-2-ylmethyl)-5,6,7,8tetrahydrobenzo[4,5]thieno[2,3-d]pyrimidin-4(3H)-one $(35 d) .{ }^{1} \mathrm{H}$ NMR $\left(400 \mathrm{MHz}\right.$, DMSO- $\left.d_{6}\right) \delta 8.62(\mathrm{~s}, 1 \mathrm{H}), 7.92-7.86(\mathrm{~m}, 3 \mathrm{H})$, $7.82(\mathrm{~d}, J=1.7 \mathrm{~Hz}, 1 \mathrm{H}), 7.52-7.50(\mathrm{~m}, 3 \mathrm{H}), 6.82-6.76(\mathrm{~m}, 2 \mathrm{H}), 6.68$ $(\mathrm{d}, J=7.0 \mathrm{~Hz}, 1 \mathrm{H}), 6.60-6.54(\mathrm{~m}, 1 \mathrm{H}), 5.35(\mathrm{~s}, 2 \mathrm{H}), 4.67(\mathrm{~d}, J=$ $8.7 \mathrm{~Hz}, 1 \mathrm{H}), 3.87-3.78(\mathrm{~m}, 1 \mathrm{H}), 3.75(\mathrm{~s}, 2 \mathrm{H}), 3.17-3.06(\mathrm{~m}, 2 \mathrm{H})$, $2.96-2.88(\mathrm{~m}, 1 \mathrm{H}), 2.76(\mathrm{dd}, J=16.8,8.4 \mathrm{~Hz}, 1 \mathrm{H}), 2.10-2.04(\mathrm{~m}$, $1 \mathrm{H}), 1.80-1.68(\mathrm{~m}, 1 \mathrm{H})$.

7-((3-Methoxyphenyl)amino)-3-(naphthalen-2-ylmethyl)-5,6,7,8tetrahydrobenzo[4,5]thieno[2,3-d]pyrimidin-4(3H)-one $(37 d) .{ }^{1} \mathrm{H}$ NMR $\left(400 \mathrm{MHz}\right.$, DMSO- $\left.d_{6}\right) \delta 8.62(\mathrm{~s}, 1 \mathrm{H}), 7.90(\mathrm{dd}, J=9.1$, $4.8 \mathrm{~Hz}, 4 \mathrm{H}), 7.83(\mathrm{~s}, 1 \mathrm{H}), 7.56-7.46(\mathrm{~m}, 3 \mathrm{H}), 6.96(\mathrm{t}, J=8.1 \mathrm{~Hz}$ $1 \mathrm{H}), 6.27-6.21(\mathrm{~m}, 1 \mathrm{H}), 6.19(\mathrm{t}, J=2.2 \mathrm{~Hz}, 1 \mathrm{H}), 6.11(\mathrm{dt}, J=7.9$, $1.5 \mathrm{~Hz}, 1 \mathrm{H}), 5.63(\mathrm{~d}, J=8.2 \mathrm{~Hz}, 1 \mathrm{H}), 5.34(\mathrm{~s}, 2 \mathrm{H}), 3.86-3.72(\mathrm{~m}$, $1 \mathrm{H}), 3.66(\mathrm{~s}, 3 \mathrm{H}), 3.65(\mathrm{~s}, 3 \mathrm{H}), 3.17-3.07(\mathrm{~m}, 4 \mathrm{H}), 2.93(\mathrm{dd}, J=17.6$, $8.8 \mathrm{~Hz}, 1 \mathrm{H}), 2.65(\mathrm{dd}, J=16.8,7.5 \mathrm{~Hz}, 1 \mathrm{H}), 2.10-2.00(\mathrm{~m}, 1 \mathrm{H})$, $1.76-1.62(\mathrm{~m}, 1 \mathrm{H})$.

3-(Quinolin-8-ylmethyl)-7-(m-tolylamino)-5, 6, 7, 8tetrahydrobenzo[4,5]thieno[2,3-d]pyrimidin-4(3H)-one $(38 e) .{ }^{1} \mathrm{H}$ NMR (400 MHz, DMSO- $\left.d_{6}\right) \delta 9.01(\mathrm{~d}, J=3.8 \mathrm{~Hz}, 1 \mathrm{H}), 8.67(\mathrm{~s}$, $1 \mathrm{H}), 8.43(\mathrm{~d}, J=8.3 \mathrm{~Hz}, 1 \mathrm{H}), 7.96(\mathrm{~d}, J=8.3 \mathrm{~Hz}, 1 \mathrm{H}), 7.67-7.53(\mathrm{~m}$, $2 \mathrm{H}), 7.46(\mathrm{~d}, J=6.9 \mathrm{~Hz}, 1 \mathrm{H}), 6.94(\mathrm{t}, J=7.6 \mathrm{~Hz}, 1 \mathrm{H}), 6.45-6.42(\mathrm{~m}$, $2 \mathrm{H}), 6.34(\mathrm{~d}, J=7.4 \mathrm{~Hz}, 1 \mathrm{H}), 5.77(\mathrm{~s}, 2 \mathrm{H}), 5.50(\mathrm{~d}, J=8.2 \mathrm{~Hz}, 1 \mathrm{H})$, $3.76(\mathrm{~s}, 1 \mathrm{H}), 3.16-3.07(\mathrm{~m}, 2 \mathrm{H}), 2.95-2.86(\mathrm{~s}, 2 \mathrm{H}), 2.17(\mathrm{~s}, 3 \mathrm{H})$, $2.08-2.00(\mathrm{~s}, 1 \mathrm{H}), 1.71-1.63(\mathrm{~s}, 1 \mathrm{H})$.

3-(Naphthalen-2-ylmethyl)-7-(p-tolylamino)-5, 6, 7, 8tetrahydrobenzo[4,5]thieno[2,3-d]pyrimidin-4(3H)-one (39d). ${ }^{1} \mathrm{H}$ NMR $\left(400 \mathrm{MHz}\right.$, DMSO- $\left.d_{6}\right) \delta 8.62(\mathrm{~s}, 1 \mathrm{H}), 7.90(\mathrm{dd}, J=9.0,4.7$ $\mathrm{Hz}, 3 \mathrm{H}), 7.83(\mathrm{~d}, J=1.7 \mathrm{~Hz}, 1 \mathrm{H}), 7.58-7.42(\mathrm{~m}, 3 \mathrm{H}), 6.88(\mathrm{~d}, J=$ $8.0 \mathrm{~Hz}, 2 \mathrm{H}), 6.55(\mathrm{~d}, J=8.4 \mathrm{~Hz}, 2 \mathrm{H}), 5.35(\mathrm{~m}, 2 \mathrm{H}), 3.77-3.70(\mathrm{~s}$, $1 \mathrm{H}), 3.17-3.02(\mathrm{~m}, 2 \mathrm{H}), 2.97-2.82(\mathrm{~m}, 1 \mathrm{H}), 2.63(\mathrm{dd}, J=16.8$, $8.0 \mathrm{~Hz}, 1 \mathrm{H}), 2.14(\mathrm{~s}, 3 \mathrm{H}), 2.06-2.02(\mathrm{~m}, 1 \mathrm{H}), 1.68(\mathrm{dt}, J=9.6$, $7.1 \mathrm{~Hz}, 1 \mathrm{H})$.

3-([1,1'-Biphenyl]-3-ylmethyl)-7-((4-fluorophenyl)amino)-5,6,7,8tetrahydrobenzo[4,5]thieno[2,3-d]pyrimidin-4(3H)-one $(40 \mathrm{i}) .{ }^{1} \mathrm{H}$ NMR $\left(400 \mathrm{MHz}, \mathrm{DMSO}-d_{6}\right) \delta 8.63(\mathrm{~s}, 1 \mathrm{H}), 7.69(\mathrm{~s}, 1 \mathrm{H}), 7.64(\mathrm{~d}$, $J=7.6 \mathrm{~Hz}, 2 \mathrm{H}), 7.59(\mathrm{~d}, J=7.9 \mathrm{~Hz}, 1 \mathrm{H}), 7.52-7.40(\mathrm{~m}, 3 \mathrm{H}), 7.42-$ $7.29(\mathrm{~m}, 2 \mathrm{H}), 6.90(\mathrm{t}, J=8.7 \mathrm{~Hz}, 2 \mathrm{H}), 6.62(\mathrm{dd}, J=8.7,4.5 \mathrm{~Hz}, 2 \mathrm{H})$, $5.54(\mathrm{~d}, J=8.4 \mathrm{~Hz}, 1 \mathrm{H}), 5.24(\mathrm{~s}, 1 \mathrm{H}), 3.73(\mathrm{~s}, 1 \mathrm{H}), 3.14-3.09(\mathrm{~m}$, $2 \mathrm{H}), 2.91(\mathrm{~d}, J=11.6 \mathrm{~Hz}, 2 \mathrm{H}), 2.05(\mathrm{~d}, J=11.5 \mathrm{~Hz}, 1 \mathrm{H}), 1.71-1.63$ $(\mathrm{m}, 1 \mathrm{H})$.

7-(Cyclopentylamino)-3-((2-methoxynaphthalen-1-yl)methyl)5,6,7,8-tetrahydrobenzo[4,5]thieno [2,3-d]pyrimidin-4(3H)-one (41a). ${ }^{1} \mathrm{H}$ NMR (400 MHz, DMSO- $\left.d_{6}\right) \delta 8.24(\mathrm{~s}, 1 \mathrm{H}), 8.18(\mathrm{~d}, J=8.6$ $\mathrm{Hz}, 1 \mathrm{H}), 8.03(\mathrm{~d}, J=10.6 \mathrm{~Hz}, 2 \mathrm{H}), 7.91(\mathrm{~d}, J=8.2 \mathrm{~Hz}, 1 \mathrm{H}), 7.59-$ $7.48(\mathrm{~m}, 2 \mathrm{H}), 7.39(\mathrm{t}, J=7.5 \mathrm{~Hz}, 1 \mathrm{H}), 5.55(\mathrm{~s}, 2 \mathrm{H}), 3.98(\mathrm{~s}, 3 \mathrm{H})$, $3.28-3.16(\mathrm{~m}, 2 \mathrm{H}), 3.12-2.93(\mathrm{~m}, 4 \mathrm{H}), 2.84-2.76(\mathrm{~m}, 1 \mathrm{H}), 2.01-$ $1.96(\mathrm{~s}, 1 \mathrm{H}), 1.81-1.75(\mathrm{~m}, 2 \mathrm{H}), 1.69-1.40(\mathrm{~m}, 4 \mathrm{H}), 1.33-1.26$ $(\mathrm{m}, 2 \mathrm{H})$.

3-((2-Methoxynaphthalen-1-yl)methyl)-7-((tetrahydro-2H-pyran4-yl)amino)-5,6,7,8-tetrahydrobenzo[4,5]thieno[2,3-d]pyrimidin4(3H)-one (42a). ${ }^{1} \mathrm{H}$ NMR (400 MHz, DMSO- $\left.d_{6}\right) \delta 8.18(\mathrm{~d}, J=$ $8.6 \mathrm{~Hz}, 1 \mathrm{H}), 8.03(\mathrm{~d}, J=9.7 \mathrm{~Hz}, 2 \mathrm{H}), 7.91(\mathrm{~d}, J=8.0 \mathrm{~Hz}, 1 \mathrm{H}), 7.58-$ $7.49(\mathrm{~m}, 2 \mathrm{H}), 7.39(\mathrm{t}, J=7.4 \mathrm{~Hz}, 1 \mathrm{H}), 5.56(\mathrm{~s}, 2 \mathrm{H}), 3.98(\mathrm{~s}, 3 \mathrm{H}), 3.81$ $(\mathrm{dt}, J=11.6,3.3 \mathrm{~Hz}, 2 \mathrm{H}), 3.13-2.96(\mathrm{~m}, 3 \mathrm{H}), 2.82-2.77(\mathrm{~m}, 2 \mathrm{H})$, 
$2.68-2.55(\mathrm{~m} 1 \mathrm{H}), 1.99-1.91(\mathrm{~m}, 1 \mathrm{H}), 1.78-1.73(\mathrm{~m}, 2 \mathrm{H}), 1.61-$ $1.50(\mathrm{~m}, 1 \mathrm{H}), 1.25-1.17(\mathrm{~m}, 2 \mathrm{H})$.

3-((4-Methoxynaphthalen-1-yl)methyl)-7-((tetrahydro-2H-pyran4-yl)amino)-5,6,7,8-tetrahydrobenzo[4,5] thieno[2,3-d]pyrimidin4(3H)-one (42c). ${ }^{1} \mathrm{H}$ NMR (400 MHz, DMSO- $\left.d_{6}\right) \delta 8.36(\mathrm{~s}, 1 \mathrm{H})$, $8.26-8.16(\mathrm{~m}, 1 \mathrm{H}), 8.12(\mathrm{~d}, J=8.4 \mathrm{~Hz}, 1 \mathrm{H}), 7.63(\mathrm{t}, J=7.6 \mathrm{~Hz}, 1 \mathrm{H})$, $7.56(\mathrm{t}, J=7.6 \mathrm{~Hz}, 1 \mathrm{H}), 7.16(\mathrm{~d}, J=8.0 \mathrm{~Hz}, 1 \mathrm{H}), 6.93(\mathrm{~d}, J=8.0 \mathrm{~Hz}$, $1 \mathrm{H}), 5.57(\mathrm{~s}, 2 \mathrm{H}), 3.95(\mathrm{~s}, 3 \mathrm{H}), 3.83(\mathrm{~d}, J=11.5 \mathrm{~Hz}, 2 \mathrm{H}), 3.17$ (s, $1 \mathrm{H}), 3.14-3.00(\mathrm{~m}, 2 \mathrm{H}), 2.88-2.79(\mathrm{~m}, 2 \mathrm{H}), 2.68-2.63(\mathrm{~m}, 1 \mathrm{H})$, $1.98(\mathrm{~d}, J=13.3 \mathrm{~Hz}, 1 \mathrm{H}), 1.78(\mathrm{t}, J=10.8 \mathrm{~Hz}, 2 \mathrm{H}), 1.64-1.49(\mathrm{~m}$, $1 \mathrm{H}), 1.31-1.17(\mathrm{~m}, 2 \mathrm{H})$.

3-((2-Methoxynaphthalen-1-yl)methyl)-7-((2-morpholinoethyl)amino)-5,6,7,8-tetrahydrobenzo[4,5]thieno[2,3-d]pyrimidin-4(3H)one (43a). ${ }^{1} \mathrm{H}$ NMR (400 MHz, DMSO- $\left.d_{6}\right) \delta 8.18$ (d, $J=8.6 \mathrm{~Hz}$, $1 \mathrm{H}), 8.08-7.99(\mathrm{~m}, 2 \mathrm{H}), 7.91(\mathrm{~d}, J=7.2 \mathrm{~Hz}, 1 \mathrm{H}), 7.59-7.49(\mathrm{~m}$, $2 \mathrm{H}), 7.43-7.34(\mathrm{~m}, 1 \mathrm{H}), 5.55(\mathrm{~d}, J=2.4 \mathrm{~Hz}, 2 \mathrm{H}), 3.98(\mathrm{~s}, 3 \mathrm{H}), 3.54$ $(\mathrm{t}, J=4.6 \mathrm{~Hz}, 4 \mathrm{H}), 3.12-2.67(\mathrm{~m}, 7 \mathrm{H}), 2.42-2.25(\mathrm{~m}, 6 \mathrm{H}), 2.02-$ $1.92(\mathrm{~m}, 1 \mathrm{H}), 1.64-1.50(\mathrm{~m}, 1 \mathrm{H})$.

3-(Naphthalen-2-ylmethyl)-7-((1,2,3,4-tetrahydronaphthalen-1yl)amino)-5, 6,7,8-tetrahydrobenzo[4,5]thieno [2,3-d]pyrimidin4(3H)-one (46d). ${ }^{1} \mathrm{H}$ NMR (400 MHz, DMSO- $\left.d_{6}\right) \delta 8.61(\mathrm{~s}, 1 \mathrm{H})$, $7.92-7.88(\mathrm{~m}, 3 \mathrm{H}), 7.82(\mathrm{~s}, 1 \mathrm{H}), 7.51(\mathrm{~d}, J=8.1 \mathrm{~Hz}, 3 \mathrm{H}), 7.34(\mathrm{~s}$, $1 \mathrm{H}), 7.15-6.96(\mathrm{~m}, 3 \mathrm{H}), 5.34(\mathrm{~s}, 2 \mathrm{H}), 3.92-3.78(\mathrm{~m}, 1 \mathrm{H}), 3.21-2.91$ $(\mathrm{m}, 3 \mathrm{H}), 2.89-2.54(\mathrm{~m}, 4 \mathrm{H}), 2.15-2.02(\mathrm{~m}, 1 \mathrm{H}), 2.02-1.50(\mathrm{~m}, 6 \mathrm{H})$.

7-(Benzo[d][1,3]dioxol-5-ylamino)-3-((4-methoxynaphthalen-1yl)methyl)-5,6,7,8-tetrahydrobenzo[4,5] thieno[2,3-d]pyrimidin$4(3 \mathrm{H})$-one $(47 \mathrm{c}) .{ }^{1} \mathrm{H}$ NMR (400 MHz, DMSO- $\left.d_{6}\right) \delta 8.37(\mathrm{~s}, 1 \mathrm{H}), 8.23$ $(\mathrm{d}, J=8.3 \mathrm{~Hz}, 1 \mathrm{H}), 8.13(\mathrm{~d}, J=8.5 \mathrm{~Hz}, 1 \mathrm{H}), 7.63(\mathrm{t}, J=7.7 \mathrm{~Hz}, 1 \mathrm{H})$, $7.56(\mathrm{t}, J=7.5 \mathrm{~Hz}, 1 \mathrm{H}), 7.18(\mathrm{~d}, J=8.0 \mathrm{~Hz}, 1 \mathrm{H}), 6.94(\mathrm{~d}, J=8.0 \mathrm{~Hz}$, $1 \mathrm{H}), 6.66(\mathrm{~d}, J=8.3 \mathrm{~Hz}, 1 \mathrm{H}), 6.37(\mathrm{~d}, J=2.2 \mathrm{~Hz}, 1 \mathrm{H}), 6.14-6.04(\mathrm{~m}$, $1 \mathrm{H}), 5.83(\mathrm{~s}, 2 \mathrm{H}), 5.59(\mathrm{~s}, 2 \mathrm{H}), 5.33(\mathrm{~d}, J=8.4 \mathrm{~Hz}, 1 \mathrm{H}), 3.96(\mathrm{~s}, 3 \mathrm{H})$, 3.79-3.64 (m, $1 \mathrm{H}), 3.21-3.04(\mathrm{~m}, 2 \mathrm{H}), 3.04-2.86(\mathrm{~m}, 1 \mathrm{H}), 2.70-$ $2.57(\mathrm{~m}, 1 \mathrm{H}), 2.15-2.00(\mathrm{~m}, 1 \mathrm{H}), 1.77-1.63(\mathrm{~m}, 1 \mathrm{H})$.

6-(2-Aminoethyl)-3-((2-methoxynaphthalen-1-yl) methyl)-5methylthieno [2,3-d] pyrimidin-4(3H)-one (56a). (See Supporting Information, Scheme SS2) To a stirred solution of $63(5.0 \mathrm{~g}$, $9.82 \mathrm{mmol})$ in $\mathrm{EtOH}(50 \mathrm{~mL})$, hydrazine hydrate $(15 \mathrm{~mL})$ was added, and the reaction mixture was heated at $90{ }^{\circ} \mathrm{C}$ for $16 \mathrm{~h}$. The progress of the reaction was monitored by TLC. After completion, the reaction was evaporated to dryness. The crude product was purified by column chromatography using $7 \% \mathrm{MeOH} /$ dichloromethane to afford 56a $(2.5 \mathrm{~g}, 67.5 \%) .{ }^{1} \mathrm{H}$ NMR $\left(400 \mathrm{MHz}, \mathrm{DMSO}-d_{6}\right) \delta 8.19(\mathrm{~d}, J=8.6 \mathrm{~Hz}$, $1 \mathrm{H}), 8.07-7.99(\mathrm{~m}, 2 \mathrm{H}), 7.95-7.87(\mathrm{~m}, 1 \mathrm{H}), 7.60-7.50(\mathrm{~m}, 2 \mathrm{H})$, 7.39 (ddd, $J=8.0,6.8,1.1 \mathrm{~Hz}, 1 \mathrm{H}), 5.55(\mathrm{~s}, 2 \mathrm{H}), 3.98(\mathrm{~s}, 3 \mathrm{H}), 2.86-$ $2.70(\mathrm{~m}, 4 \mathrm{H}), 2.43(\mathrm{~s}, 3 \mathrm{H}), 2.12(\mathrm{br}, \mathrm{s}, 2 \mathrm{H})$.

2-(4-Oxopentyl) Isoindoline-1,3-dione (59). (See Supporting Information, Scheme SS2) To a stirred solution of 58 (20 g, $166 \mathrm{mmol})$ in DMF $(150 \mathrm{~mL}), \mathrm{K}_{2} \mathrm{CO}_{3}(46 \mathrm{~g}, 333 \mathrm{mmol})$ and 5-chloropentan-2-one $(26.9 \mathrm{~g}, 183 \mathrm{mmol})$ were added. The reaction mixture was heated at $80^{\circ} \mathrm{C}$ for $16 \mathrm{~h}$. The progress of the reaction was monitored by TLC. After completion of the reaction, the reaction mixture was quenched with ice water and filtered. The residue was washed with water, filtered, and concentrated under reduced pressure. The crude material was used for the next reaction without purification to afford title compound 59 ( $20 \mathrm{~g}$, crude).

Ethyl 2-Amino-5-(2-(1,3-dioxoisoindolin-2-yl)ethyl)-4-methylthiophene-3-carboxylate (60). (See Supporting Information, Scheme SS2) To a stirred solution of compound $59(15 \mathrm{~g}, 64.9 \mathrm{mmol})$ and ethyl 2-cyanoacetate $(8.0 \mathrm{~g}, 71.4 \mathrm{mmol})$ in EtOH $(200 \mathrm{~mL})$, morpholine $(19.5 \mathrm{~mL})$ and sulfur $(2.3 \mathrm{~g}, 72 \mathrm{mmol})$ were added and stirred at $50{ }^{\circ} \mathrm{C}$ for $16 \mathrm{~h}$. The progress of the reaction was monitored by TLC. After completion of the reaction, the reaction mixture was quenched with water and extracted with EtOAc. The combined organic layer was washed with brine, dried over anhydrous $\mathrm{Na}_{2} \mathrm{SO}_{4}$, and concentrated under reduced pressure. The crude product was purified by column chromatography using $40 \%$ EtOAc/hexane to afford title compound $\mathbf{6 0}$ (10.2 g, 44\%). LCMS: $358.99(\mathrm{M}+\mathrm{H})$.

2-(2-(5-Methyl-4-oxo-3,4-dihydrothieno[2,3-d]pyrimidin-6-yl)ethyl)isoindoline-1,3-dione (61). (See Supporting Information, Scheme SS2) To a stirred solution of compound $\mathbf{6 0}(10.2 \mathrm{~g}, 28.4 \mathrm{mmol})$ in formamide $(120 \mathrm{~mL})$, ammonium formate $(3.58 \mathrm{~g}, 56.9 \mathrm{mmol})$ was added and stirred at $120^{\circ} \mathrm{C}$ for $16 \mathrm{~h}$. The progress of the reaction was monitored by TLC. After completion of the reaction, the reaction mixture was quenched with ice water, and the precipitated solid was filtered. The crude product was purified by column chromatography using 5\% MeOH/dichloromethane to afford title compound 61 (6.0 g, $62.5 \%) .{ }^{1} \mathrm{H}$ NMR (400 MHz, DMSO- $\left.d_{6}\right) \delta 12.3$ (brs, $\left.1 \mathrm{H}\right), 7.99(\mathrm{~d}, J=$ $8.4 \mathrm{~Hz}, 1 \mathrm{H}), 7.85(\mathrm{~d}, J=7.8 \mathrm{~Hz}, 4 \mathrm{H}), 3.80(\mathrm{t}, 2 \mathrm{H}), 3.14-3.11(\mathrm{~m}, 2 \mathrm{H})$, $2.34(\mathrm{~s}, 3 \mathrm{H})$.

1-(Bromomethyl)-2-methoxynaphthalene (62). (See Supporting Information, Scheme SS2) To a stirred solution of 2-methoxy-1naphthaldehyde $(15 \mathrm{~g}, 80.6 \mathrm{mmol})$ in EtOH $(200 \mathrm{~mL}), \mathrm{NaBH}_{4}(6.2 \mathrm{~g}$, $161 \mathrm{mmol}$ ) was added and stirred at room temperature for $3 \mathrm{~h}$. The progress of the reaction was monitored by TLC. After completion of the reaction, the reaction mixture was concentrated under reduced pressure. The residue was dissolved in water and extracted with dichloromethane. The combined organic layer was washed with brine, dried over anhydrous $\mathrm{Na}_{2} \mathrm{SO}_{4}$, and concentrated under reduced pressure. The crude product was dissolved in dichloromethane $(200 \mathrm{~mL})$, and $\mathrm{PBr}_{3}(32.7 \mathrm{~g}, 120 \mathrm{mmol})$ was added dropwise, and the reaction mixture was allowed to stir at room temperature for $1 \mathrm{~h}$. After completion of the reaction, the reaction mixture was quenched with water and extracted with dichloromethane. The combined organic layer was washed with brine, dried over anhydrous $\mathrm{Na}_{2} \mathrm{SO}_{4}$, and concentrated under reduced pressure to afford title compound $\mathbf{6 2}$ (10.2 g, crude).

2-(2-(3-((2-Methoxynaphthalen-1-yl)methyl)-5-methyl-4-oxo3,4-dihydrothieno[2,3-d]pyrimidin-6-yl)ethyl)isoindoline-1,3-dione (63). (See Supporting Information, Scheme SS2) To a stirred solution of $61(6 \mathrm{~g}, 17.6 \mathrm{mmol})$ in DMF $(60 \mathrm{~mL}), \mathrm{Cs}_{2} \mathrm{CO}_{3}(11.6 \mathrm{~g}, 35.3 \mathrm{mmol})$ and $62(6.6 \mathrm{~g}, 26.5 \mathrm{mmol})$ were added. The reaction mixture was allowed to stir at room temperature for $16 \mathrm{~h}$. The progress of the reaction was monitored by TLC. After completion of the reaction, the reaction mixture was quenched with ice water and filtered. The residue was washed with water, filtered, and concentrated under reduced pressure. The crude material was used for the next reaction without purification to afford title compound 63 (5.0 g, crude). LCMS: 510.07( $\mathrm{M}+\mathrm{H})$.

SIRT Enzymatic Assays. Enzymatic assays were performed by Reaction Biology Corporation (http://www.reactionbiology.com) as described before. ${ }^{81}$ In vitro SIRT assays were conducted by using the fluorogenic peptide substrate from $\mathrm{p} 53$ residues $379-382$ RHKK(Ac)AMC for SIRT1-3. The assay buffer contained $50 \mathrm{mM}$ Tris- $\mathrm{HCl}$, $\mathrm{pH}$ 8.0, $137 \mathrm{mM} \mathrm{NaCl}, 2.7 \mathrm{mM} \mathrm{KCl}, 1 \mathrm{mM} \mathrm{MgCl}_{2}, 1 \mathrm{mg} \mathrm{mL}^{-1}$ bovine serum albumin, and $1 \%$ DMSO. The protocol involved a two-step procedure. The fluorogenic substrate with the acetylated lysine side chain was incubated with the SIRT enzyme to produce the deacetylated products, which were then digested in the second step by the addition of a developer to produce the fluorescent signal proportional to the amount of deacetylated substrates. Deacetylation of substrate peptides was used as a read out of the SIRT activity. All compounds were freshly prepared as $10 \mathrm{mM}$ stock solutions in DMSO and serially diluted to the indicated concentration in the reaction. All test compounds were preincubated with the human SIRTs for about 10 min before commencing the reaction through the addition of substrate. Fluorescence was read $\left(\lambda_{\mathrm{ex}}, 360 \mathrm{~nm} ; \lambda_{\mathrm{em}}, 460 \mathrm{~nm}\right)$ using an EnVision Multilabel Plate Reader (PerkinElmer). The percentages of enzyme activity (relative to DMSO controls) and $\mathrm{IC}_{50}$ values were calculated using the GraphPad Prism 4 program based on a sigmoidal dose-response equation. The number of replicates is stated in the corresponding text.

Tubulin Acetylation Assay. Cell Lines and Cell Culture. Human breast cancer cell line MCF-7 (Michigan Cancer Foundation-7) originated from the American Type Culture Collection (ATCC) were obtained from the Cell Culture Service of Cancer Research UK, where they were tested and authenticated. Cells were maintained in Dulbecco's modified Eagle's medium (DMEM, Sigma-Aldrich, Poole, UK) and supplemented with $10 \%$ fetal calf serum (FCS, First Link Ltd., Birmingham, UK), 100 Unit/mL penicillin/streptomycin (SigmaAldrich, UK), and $2 \mathrm{mM}$ glutamine under $10 \% \mathrm{CO}_{2}$ humidified atmosphere at a constant temperature of $37^{\circ} \mathrm{C} .{ }^{91}$ 
Time Course and Treatment. MCF-7 cells were cultured in DMEM and treated with varied concentrations $(0,1,10,20,30$, and $50 \mu \mathrm{M}$ ) of compounds and $50 \mathrm{nM}$ trichostatin A (TSA) (T8552, Sigma-Aldrich, UK) for $24 \mathrm{~h}$. TSA was used to abolish the activity of non-sirtuin HDAC members.

Protein Preparation. After treatment, MCF-7 cells were harvested by centrifugation at $2000 \mathrm{rpm}$ for $5 \mathrm{~min}$, the supernatant was discarded, and the pellets were stored at $-80{ }^{\circ} \mathrm{C}$ in a freezer until lysis was performed. Cell lysis was performed in 2 volumes of NP40 lysis buffer $\left[1 \%(\mathrm{v} / \mathrm{v})\right.$ Nonidet P-40, $150 \mathrm{NaCl}_{2}, 50 \mathrm{mM}$ Tris- $\mathrm{HCl}$ (7.6), $5 \mathrm{mM}$ EDTA, $1 \mathrm{mM}$ dithiothreitol (DTT), $1 \mathrm{mM} \mathrm{NaF}, 2 \mathrm{mM}$ phenylmethylsulfonyl fluoride (PMSF), $1 \mathrm{mM}$ sodium orthovanadate, and $1 \times$ complete protease inhibitor cocktail] as instructed by the manufacturer (Roche Diagnostics, Burgess Hill, West Sussex, UK)] for $10 \mathrm{~min}$ at $4{ }^{\circ} \mathrm{C}$. Vortexing and pipetting were employed to facilitate the lysis. The samples were then centrifuged at $13000 \mathrm{rpm}$ at $4{ }^{\circ} \mathrm{C}$ for $10 \mathrm{~min}$. The supernatant was collected as a protein lysate and transferred to a clean Eppendorf tube prior to measurement.

To determine protein concentration, Pierce BCA Protein Assay Reagents A and B (Thermo Scientific) were employed according to the manufacturer's instructions. Absorbance was read at $562 \mathrm{~nm}$ using the Sunrise spectrophotometer (Tecan, Reading, UK), and absorbance readouts were utilized to assay protein concentration according to the equation of absorbance $\times 25=\mu \mathrm{g} / \mu \mathrm{L}$.

Western Blotting. SDS-PAGE gels consisted of an upper stacking and a lower running gel. The running gel was made with varying amounts of bis-acrylamide solution, according to the molecular size of the protein being isolated, with percentages of gels used varying from 7 to 14. Lower percentage gels allowed better examination of higher molecular weight proteins and vice versa. The bis-acrylamide with ammonium persulfate (APS) and tetramethylethylenediamine (TEMED) were used as the catalysts for gel polymerization.

Protein separation was obtained by diluting $20 \mu \mathrm{g}$ of protein lysate with $2 \times$ SDS loading buffer $(200 \mathrm{mM}$ Tris- $\mathrm{HCl}$ at $\mathrm{pH} 6.8,6 \%$ sodium dodecyl sulfate (SDS), $2 \mathrm{mM}$ EDTA, 10\% 2-mercaptoethanol, 10\% glycerol, and $0.02 \%$ bromophenol blue) and proteins denatured from 5 min at $100{ }^{\circ} \mathrm{C}$.

Samples were then loaded into the SDS-PAGE gels and fractionated for $2 \mathrm{~h}$ at $90 \mathrm{~V}$ using a Mini-Protean III apparatus (Bio-Rad Laboratories, Hemel Hempstead, UK). Once SDS-PAGE had finished, proteins were electro-transferred onto $0.45 \mu \mathrm{m}$ Protran nitrocellulose membranes (Schleicher and Schuell, Whatman, Brentford, UK) in transfer buffer [ $25 \mathrm{mM}$ tris, $190 \mathrm{mM}$ glycine, and 20\% (v/v) ethanol] for $90 \mathrm{~min}$ at $90 \mathrm{~V}$ and room temperature by using the Bio-Rad TransBlot Cell wet transfer system.

Membranes were blocked in $5 \%(\mathrm{w} / \mathrm{v})$ biovine serum albumin (BSA) in Tris buffered solution with $0.05 \%$ Tween-20 (TBST, pH 7.5) for $30 \mathrm{~min}$ at room temperature. Primary antibody incubation was performed with antibodies diluted in a 5\% BSA-TBST solution overnight at $4{ }^{\circ} \mathrm{C}$. The membranes were washed four times with TBST, every $5 \mathrm{~min}$ with $50 \mathrm{~mL}$ of TBST at room temperature. Membranes were then incubated in their respective secondary antibodies (SantaCruz Biotech antirabbit or antimouse) coupled with horseradish peroxidase (Dako, Ely, UK) at a 1:2000 dilution for $30 \mathrm{~min}$ at room temperature. Subsequent to $5 \times 5 \mathrm{~min}$ washes in TBST to remove excess secondary antibodies were performed. Proteins were visualized using an enhanced chemiluminescence (ECL) detection system (GE Healthcare, UK). ${ }^{92}$

Primary antibodies and respective dilutions used were shown as follows: antiacetyl alpha tubulin antibody (Lys40) (D20G3), 5335s, rabbit monoclonal, Cell signaling Technology, 1:1000; antialpha tubulin antibody, DM1A, ab7291, mouse monoclonal, Abcam, 1:2000; anti- $\beta$-actin antibody, sc-1616R, and rabbit polyclonal, Santa Cruz Biotechnology, 1:2000.

Molecular Modeling Methods. All calculations were performed on a Windows 7.0 based Workstation using the Maestro 10.6 graphical user interface (GUI) of the Schrodinger software suite (Schrödinger, LLC, New York, NY, 2016). ${ }^{93}$

Protein Preparation. The X-ray structure of SIRT2-29c was prepared using the Protein Preparation Wizard. All water molecules and ions were deleted; atom types and bond orders were corrected, and the hydrogen atoms were reassigned after deleting the original ones. Missing side chains were added using the Prime 4.1 program. ${ }^{94,95}$ The protonation states of acidic/basic amino acids were adjusted for $\mathrm{pH}$ 7.0. Restrained minimization of the protein was performed employing the OPLS-2005 force fields ${ }^{96}$ with the convergence criteria of RMSD of $0.3 \AA$ for heavy atoms.

Ligand Preparation. All molecules were drawn in ChemDraw Pro 13.0 and prepared using the LigPrep wizard of the Schrodinger Suite which utilizes Epik $3.6^{97,98}$ to generate energetically accessible protonation states and all possible stereoisomers. No tautomeric forms were generated for the ligands.

Docking. A receptor grid was generated using the centroid of the cocrystallized ligand $29 \mathrm{c}$ with default settings for the size of the enclosing box. All other default settings were used. The ligands were docked into the prepared protein using the Glide 7.1 program $^{99-101}$ implemented in Schrodinger Suite using the standard precision (SP) mode. ${ }^{100}$ No constraints were applied to the docking. Ligands were sampled throughout the docking, including ring conformations. Amide bonds were penalized in their nonplanar conformation. Epik state penalties were added to the final score. A maximum of 10 poses per ligand were allowed, and postdocking minimization was also allowed.

Cheminformatic Analysis. The cLogP for all molecules was calculated in their neutral state using Datawarrior. ${ }^{102}$ All thienopyrimidinone analogues except 9a, 17a, and 19a (percentage inhibition at $10 \mu \mathrm{M}$ not available) were used for the analysis (total $=248$ ).

Table 4. Diffraction Data and Refinement Statistics

\begin{tabular}{|c|c|}
\hline & SIRT2-29c \\
\hline \multicolumn{2}{|c|}{ Data Collection Statistics } \\
\hline resolution range & $45.17-2.07(2.19-2.07)$ \\
\hline space group & $\mathbf{P} 12_{1} 1$ \\
\hline unit cell $(\mathrm{a}, \mathrm{b}, \mathrm{c} ; \beta)$ & $59.68 \AA ̊, 68.56 \AA$, $78.46 \AA ; 95.66^{\circ}$ \\
\hline total reflections & $102179(15673)$ \\
\hline unique reflections & $38188(6077)$ \\
\hline multiplicity & $2.7(2.6)$ \\
\hline completeness (\%) & $98.9(98.1)$ \\
\hline mean $I /$ sigma $(I)$ & $9.82(2.37)$ \\
\hline Wilson $B$-factor $\left(\AA^{2}\right)$ & 29.7 \\
\hline$R$-meas ${ }^{a}$ & $10.9(53.1)$ \\
\hline $\mathrm{CC} 1 / 2^{b}$ & $99.5(77.0)$ \\
\hline \multicolumn{2}{|c|}{ Refinement Statistics } \\
\hline resolution range $(\AA)$ & $44.9-2.07(2.14-2.07)$ \\
\hline reflections used in refinement & $38175(3754)$ \\
\hline reflections used for $R$-free & $1910(188)$ \\
\hline$R$-work & $0.1646(0.2485)$ \\
\hline$R$-free & $0.2049(0.3098)$ \\
\hline number of non-hydrogen atoms & 5406 \\
\hline macromolecules & 4820 \\
\hline ligands $(29 c)$ & 36 \\
\hline solvent & 446 \\
\hline protein residues & 598 \\
\hline RMS(bonds) (A) & 0.005 \\
\hline RMS(angles) (deg) & 0.72 \\
\hline Ramachandran favored (\%) & 97.5 \\
\hline outliers (\%) & 0.17 \\
\hline rotamer outliers (\%) & 0.76 \\
\hline clashscore & 0.92 \\
\hline average $B$-factor $\left(\AA^{2}\right)$ & 32.9 \\
\hline macromolecules & 32.3 \\
\hline ligands $(29 c)$ & 23.8 \\
\hline solvent & 36.0 \\
\hline
\end{tabular}

${ }^{a}$ Redundancy independent $R$-factor. ${ }^{109}{ }^{b}$ Percentage of correlation between intensities from random half-data sets. ${ }^{110}$ 
The actives were defined as analogues with more than $80 \%$ inhibition at $10 \mu \mathrm{M}$, while inactives were defined as those with less than $50 \%$ inhibition at $10 \mu \mathrm{M}$. The structure and activity data for the aminothiazole series were taken from Schiedel et al. ${ }^{79}$ For this series, the actives were defined as analogues with $\mathrm{IC}_{50}$ values less than $5 \mu \mathrm{M}$ (total $=17)$, while inactives were defined as those which showed inhibition at only $50 \mu \mathrm{M}$ (total $=20)$. In the case of analogues with chiral centers, the activity of the racemate was used.

X-ray Crystallography. Protein Production and Crystallization. Sirt2 56-356 was cloned in a modified pET-19 vector which expresses the protein of interest with a $\mathrm{N}$-terminal His6-SUMO tag. Expression was carried out in E. coli codon+ cells in autoinduction media at $20^{\circ} \mathrm{C}$. Purification was performed as described in Di Fruscia et al. ${ }^{81}$ and included an affinity chromatography step followed by digestion of the expression tag in the presence of Sumo protease $(1 / 100 \mathrm{w} / \mathrm{w})$ and gel filtration on a $S 20016 / 60$ (GE Healthcare) in $20 \mathrm{mM}$ Tris at pH 8.0, $150 \mathrm{mM} \mathrm{NaCl}$, and $1 \mathrm{mM}$ TCEP. Crystals of the complex between SIRT2 and 29c were obtained by cocrystallization at $4{ }^{\circ} \mathrm{C}$ using a vapor diffusion method. Prior to crystallization, the protein at $15 \mathrm{mg} \cdot \mathrm{mL}^{-1}$ was incubated on ice for at least an hour with $1 \mathrm{mM}$ 29c (final DMSO concentration 5\%). Crystals of a maximal dimension of $50 \mu \mathrm{m} \times 20 \mu \mathrm{m} \times 20 \mu \mathrm{m}$ grew within 2 weeks from drops containing equal volumes of the protein/ligand mix and $2.6 \mathrm{M}$ ammonium sulfate, 5\% PEG 300, and 0.1 M MES buffer at pH 5.83 .

Diffraction Data Collection and Structure Solution. After a short soaking period in a cryo protecting solution composed of the mother liquor supplemented with $25 \%$ glycerol (v/v) and $1 \mathrm{mM} \mathrm{29c}$, crystals were mounted on a nylon loop and flash frozen in liquid nitrogen. Diffraction data were collected on BL14.1 operated by the Helmholtz-Zentrum Berlin (HZB) at the BESSY II electron storage ring (Berlin-Adlershof, Germany) $)^{103}$ at $100 \mathrm{~K}$ using a Pilatus $6 \mathrm{M}$ detector (Dectris) and a wavelength of $0.9184 \AA$ A. Statistics of the diffraction data integrated using $\mathrm{XDSAPP}^{104}$ can be found in Table 4 . The structure was solved by molecular replacement using Molrep ${ }^{105}$ and one molecule of Sirt2 (PDB ID: 4RMG) ${ }^{77}$ as a model. Structure refinement was carried out by alternating rounds of positional refinement by phenix.refine ${ }^{106}$ and manual rebuilding in Coot. ${ }^{107}$

\section{ASSOCIATED CONTENT}

\section{S Supporting Information}

The Supporting Information is available free of charge on the ACS Publications website at DOI: 10.1021/acs.jmedchem.6b01690.

Synthetic methods, spectral data, and LCMS methods/ data (PDF)

Molecular strings for all the compounds reported in this study (CSV)

\section{Accession Codes}

The final model and the structure factors of SIRT2 bound to 29c are deposited to the Protein Databank under accession code 5MAT. Authors will release the atomic coordinates and experimental data upon article publication.

\section{AUTHOR INFORMATION}

\section{Corresponding Author}

*Tel: +44 (0)2075945815. Fax: +44 (0)2075945805. E-mail: m.fuchter@imperial.ac.uk.

\section{ORCID ${ }^{\oplus}$}

Matthew J. Fuchter: 0000-0002-1767-7072

\section{Author Contributions}

${ }^{\#}$ S.S. and S.M. contributed equally to this work.

\section{Notes}

The authors declare no competing financial interest.

\section{ACKNOWLEDGMENTS}

We thank the Imperial Confidence in Concept scheme and the NIHR Imperial BRC for funding this work. S.S. acknowledges the financial support from Cancer Research UK (C33325/ A19435). S.M. and C.S. thank the BESSY beamline staff for technical support and CS support by Alzheimer Forschung Initiative eV (grant \#14834). E.W.F.L.'s work is supported by MRC (MR/N012097/1), CRUK (A12011) and Breast Cancer Now (2012MayPR070; 2012NovPhD016). Z.M. is funded by a scholarship from the Commonwealth Scholarship Commission (BDCS-2015-63).

\section{ABBREVIATIONS USED}

SIRT, sirtunins; H3K9ac, histone 3 lysine 9 acylation; PKM2, pyruvate kinase 2; DMI, dimethylisoxazole; DMP, dimethylpyrimidine

\section{REFERENCES}

(1) Sauve, A. A. Sirtuin chemical mechanisms. Biochim. Biophys. Acta, Proteins Proteomics 2010, 1804, 1591-1603.

(2) North, B. J.; Verdin, E. Sirtuins: Sir2-related NAD-dependent protein deacetylases. Genome Biol. 2004, 5, 224.

(3) Frye, R. A. Phylogenetic classification of prokaryotic and eukaryotic Sir2-like proteins. Biochem. Biophys. Res. Commun. 2000, 273, 793-798.

(4) Du, J.; Zhou, Y.; Su, X.; Yu, J. J.; Khan, S.; Jiang, H.; Kim, J.; Woo, J.; Kim, J. H.; Choi, B. H.; He, B.; Chen, W.; Zhang, S.; Cerione, R. A.; Auwerx, J.; Hao, Q.; Lin, H. Sirt5 is an NAD-dependent protein lysine demalonylase and desuccinylase. Science 2011, 334, 806-809.

(5) Teng, Y. B.; Jing, H.; Aramsangtienchai, P.; He, B.; Khan, S.; Hu, J.; Lin, H.; Hao, Q. Efficient demyristoylase activity of SIRT2 revealed by kinetic and structural studies. Sci. Rep. 2015, 5, 8529.

(6) Jiang, H.; Khan, S.; Wang, Y.; Charron, G.; He, B.; Sebastian, C.; Du, J.; Kim, R.; Ge, E.; Mostoslavsky, R.; Hang, H. C.; Hao, Q.; Lin, H. SIRT6 regulates TNF-alpha secretion through hydrolysis of longchain fatty acyl lysine. Nature 2013, 496, 110-113.

(7) Jin, J.; He, B.; Zhang, X.; Lin, H.; Wang, Y. SIRT2 reverses 4oxononanoyl lysine modification on histones. J. Am. Chem. Soc. 2016, $138,12304-12307$

(8) Jing, H.; Lin, H. Sirtuins in epigenetic regulation. Chem. Rev. 2015, 115, 2350-2375.

(9) Imai, S.; Armstrong, C. M.; Kaeberlein, M.; Guarente, L. Transcriptional silencing and longevity protein Sir2 is an NADdependent histone deacetylase. Nature 2000, 403, 795-800.

(10) Vaquero, A.; Scher, M. B.; Lee, D. H.; Sutton, A.; Cheng, H. L.; Alt, F. W.; Serrano, L.; Sternglanz, R.; Reinberg, D. SirT2 is a histone deacetylase with preference for histone $\mathrm{H} 4$ Lys 16 during mitosis. Genes Dev. 2006, 20, 1256-1261.

(11) Hsu, W. W.; Wu, B.; Liu, W. R. Sirtuins 1 and 2 are universal histone deacetylases. ACS Chem. Biol. 2016, 11, 792-799.

(12) Martínez-Redondo, P.; Vaquero, A. The diversity of histone versus nonhistone sirtuin substrates. Genes Cancer 2013, 4, 148-163.

(13) Longo, V. D.; Kennedy, B. K. Sirtuins in aging and age-related disease. Cell 2006, 126, 257-268.

(14) Watroba, M.; Szukiewicz, D. The role of sirtuins in aging and age-related diseases. Adv. Med. Sci. 2016, 61, 52-62.

(15) Trapp, J.; Jung, M. The role of NAD+ dependent histone deacetylases (sirtuins) in ageing. Curr. Drug Targets 2006, 7, 15531560.

(16) Galli, M.; Van Gool, F.; Leo, O. Sirtuins and inflammation: Friends or foes? Biochem. Pharmacol. 2011, 81, 569-576.

(17) Lee, A. S.; Jung, Y. J.; Kim, D.; Nguyen-Thanh, T.; Kang, K. P.; Lee, S.; Park, S. K.; Kim, W. SIRT2 ameliorates lipopolysaccharideinduced inflammation in macrophages. Biochem. Biophys. Res. Commun. 2014, 450, 1363-1369. 
(18) Vachharajani, V. T.; Liu, T.; Wang, X.; Hoth, J. J.; Yoza, B. K.; McCall, C. E. Sirtuins link inflammation and metabolism. J. Immunol. Res. 2016, 2016, 8167273.

(19) Yuan, F.; Xu, Z. M.; Lu, L. Y.; Nie, H.; Ding, J.; Ying, W. H.; Tian, H. L. SIRT2 inhibition exacerbates neuroinflammation and blood-brain barrier disruption in experimental traumatic brain injury by enhancing NF-kappaB p65 acetylation and activation. J. Neurochem. 2016, 136, 581-593.

(20) Chakraborty, C.; Doss, C. G. Sirtuins family-recent development as a drug target for aging, metabolism, and age related diseases. Curr. Drug Targets 2013, 14, 666-675.

(21) Chang, H. C.; Guarente, L. SIRT1 and other sirtuins in metabolism. Trends Endocrinol. Metab. 2014, 25, 138-145.

(22) Choi, J. E.; Mostoslavsky, R. Sirtuins, metabolism, and DNA repair. Curr. Opin. Genet. Dev. 2014, 26, 24-32.

(23) Jeong, S. M.; Haigis, M. C. Sirtuins in cancer: A balancing act between genome stability and metabolism. Mol. Cells 2015, 38, 750758.

(24) Kleszcz, R.; Paluszczak, J.; Baer-Dubowska, W. Targeting aberrant cancer metabolism - The role of sirtuins. Pharmacol. Rep. 2015, 67, 1068-1080.

(25) Lee, I. H.; Yun, J.; Finkel, T. The emerging links between sirtuins and autophagy. Methods Mol. Biol. 2013, 1077, 259-271.

(26) Ng, F.; Tang, B. L. Sirtuins' modulation of autophagy. J. Cell. Physiol. 2013, 228, 2262-2270.

(27) Gal, J.; Bang, Y.; Choi, H. J. SIRT2 interferes with autophagymediated degradation of protein aggregates in neuronal cells under proteasome inhibition. Neurochem. Int. 2012, 61, 992-1000.

(28) Inoue, T.; Nakayama, Y.; Li, Y.; Matsumori, H.; Takahashi, H.; Kojima, H.; Wanibuchi, H.; Katoh, M.; Oshimura, M. SIRT2 knockdown increases basal autophagy and prevents postslippage death by abnormally prolonging the mitotic arrest that is induced by microtubule inhibitors. FEBS J. 2014, 281, 2623-2637.

(29) Lombard, D. B. Sirtuins at the breaking point: SIRT6 in DNA repair. Aging 2009, 1, 12-16.

(30) Rice, C. M.; Sun, M.; Kemp, K.; Gray, E.; Wilkins, A.; Scolding, N. J. Mitochondrial sirtuins-a new therapeutic target for repair and protection in multiple sclerosis. Eur. J. Neurosci. 2012, 35, 1887-1893.

(31) Anderson, E. N.; Corkins, M. E.; Li, J. C.; Singh, K.; Parsons, S.; Tucey, T. M.; Sorkac, A.; Huang, H.; Dimitriadi, M.; Sinclair, D. A.; Hart, A. C. C. elegans lifespan extension by osmotic stress requires FUdR, base excision repair, FOXO, and sirtuins. Mech. Ageing Dev. 2016, 154, 30-42.

(32) Oberdoerffer, P.; Michan, S.; McVay, M.; Mostoslavsky, R.; Vann, J.; Park, S. K.; Hartlerode, A.; Stegmuller, J.; Hafner, A.; Loerch, P.; Wright, S. M.; Mills, K. D.; Bonni, A.; Yankner, B. A.; Scully, R.; Prolla, T. A.; Alt, F. W.; Sinclair, D. A. SIRT1 redistribution on chromatin promotes genomic stability but alters gene expression during aging. Cell 2008, 135, 907-918.

(33) Wang, R. H.; Sengupta, K.; Li, C.; Kim, H. S.; Cao, L.; Xiao, C.; Kim, S.; Xu, X.; Zheng, Y.; Chilton, B.; Jia, R.; Zheng, Z. M.; Appella, E.; Wang, X. W.; Ried, T.; Deng, C. X. Impaired DNA damage response, genome instability, and tumorigenesis in SIRT1 mutant mice. Cancer Cell 2008, 14, 312-323.

(34) Chalkiadaki, A.; Guarente, L. The multifaceted functions of sirtuins in cancer. Nat. Rev. Cancer 2015, 15, 608-624.

(35) Voelter-Mahlknecht, S.; Mahlknecht, U. The sirtuins in the pathogenesis of cancer. Clin. Epigenet. 2010, 1, 71-83.

(36) Sebastian, C.; Mostoslavsky, R. The role of mammalian sirtuins in cancer metabolism. Semin. Cell Dev. Biol. 2015, 43, 33-42.

(37) Soung, Y. H.; Pruitt, K.; Chung, J. Epigenetic silencing of ARRDC3 expression in basal-like breast cancer cells. Sci. Rep. 2014, 4, 3846.

(38) Zhao, D.; Mo, Y.; Li, M.-T.; Zou, S.-W.; Cheng, Z.-L.; Sun, Y.P.; Xiong, Y.; Guan, K.-L.; Lei, Q.-Y. NOTCH-induced aldehyde dehydrogenase $1 \mathrm{~A} 1$ deacetylation promotes breast cancer stem cells. $J$. Clin. Invest. 2014, 124, 5453-5465.
(39) Li, Z.; Huang, J.; Yuan, H.; Chen, Z.; Luo, Q.; Lu, S. SIRT2 inhibits non-small cell lung cancer cell growth through impairing Skp2mediated p27 degradation. Oncotarget 2016, 7, 18927-18939.

(40) Kim, H. S.; Vassilopoulos, A.; Wang, R. H.; Lahusen, T.; Xiao, Z.; Xu, X.; Li, C.; Veenstra, T. D.; Li, B.; Yu, H.; Ji, J.; Wang, X. W.; Park, S. H.; Cha, Y. I.; Gius, D.; Deng, C. X. SIRT2 maintains genome integrity and suppresses tumorigenesis through regulating APC/C activity. Cancer Cell 2011, 20, 487-499.

(41) Serrano, L.; Martinez-Redondo, P.; Marazuela-Duque, A.; Vazquez, B. N.; Dooley, S. J.; Voigt, P.; Beck, D. B.; KaneGoldsmith, N.; Tong, Q.; Rabanal, R. M.; Fondevila, D.; Munoz, P.; Kruger, M.; Tischfield, J. A.; Vaquero, A. The tumor suppressor SirT2 regulates cell cycle progression and genome stability by modulating the mitotic deposition of H4K20 methylation. Genes Dev. 2013, 27, 639653.

(42) Zhao, D.; Zou, S.-W.; Liu, Y.; Zhou, X.; Mo, Y.; Wang, P.; Xu, Y.-H.; Dong, B.; Xiong, Y.; Lei, Q.-Y.; Guan, K.-L. Lysine-5 acetylation negatively regulates lactate dehydrogenase $\mathrm{A}$ and is decreased in pancreatic cancer. Cancer Cell 2013, 23, 464-476.

(43) Jing, H.; Hu, J.; He, B.; Negron Abril, Y. L.; Stupinski, J.; Weiser, K.; Carbonaro, M.; Chiang, Y. L.; Southard, T.; Giannakakou, P.; Weiss, R. S.; Lin, H. A SIRT2-selective inhibitor promotes c-Myc oncoprotein degradation and exhibits broad anticancer activity. Cancer Cell 2016, 29, 297-310.

(44) Park, S.-H.; Ozden, O.; Liu, G.; Song, H. Y.; Zhu, Y.; Yan, Y.; Zou, X.; Kang, H.-J.; Jiang, H.; Principe, D. R.; Cha, Y.-I.; Roh, M.; Vassilopoulos, A.; Gius, D. SIRT2-mediated deacetylation and tetramerization of pyruvate kinase directs glycolysis and tumor growth. Cancer Res. 2016, 76, 3802-3812.

(45) Kitada, M.; Kume, S.; Kanasaki, K.; Takeda-Watanabe, A.; Koya, D. Sirtuins as possible drug targets in type 2 diabetes. Curr. Drug Targets 2013, 14, 622-636.

(46) Huynh, F. K.; Hershberger, K. A.; Hirschey, M. D. Targeting sirtuins for the treatment of diabetes. Diabetes Manage. 2013, 3, 245257.

(47) Turkmen, K.; Karagoz, A.; Kucuk, A. Sirtuins as novel players in the pathogenesis of diabetes mellitus. World J. Diabetes 2014, 5, 894900.

(48) Eskandarian, H. A.; Impens, F.; Nahori, M. A.; Soubigou, G.; Coppee, J. Y.; Cossart, P.; Hamon, M. A. A role for SIRT2-dependent histone H3K18 deacetylation in bacterial infection. Science 2013, 341, 1238858.

(49) Matsushima, S.; Sadoshima, J. The role of sirtuins in cardiac disease. Am. J. Physiol. Heart Circ. Physiol. 2015, 309, H1375-89.

(50) de Oliveira, R. M.; Pais, T. F.; Outeiro, T. F. Sirtuins: common targets in aging and in neurodegeneration. Curr. Drug Targets 2010, $11,1270-1280$

(51) Outeiro, T. F.; Marques, O.; Kazantsev, A. Therapeutic role of sirtuins in neurodegenerative disease. Biochim. Biophys. Acta, Mol. Basis Dis. 2008, 1782, 363-369.

(52) Gan, L.; Mucke, L. Paths of convergence: sirtuins in aging and neurodegeneration. Neuron 2008, 58, 10-14.

(53) Anekonda, T. S.; Reddy, P. H. Neuronal protection by sirtuins in Alzheimer's disease. J. Neurochem. 2006, 96, 305-313.

(54) Avalos, J. L.; Bever, K. M.; Wolberger, C. Mechanism of sirtuin inhibition by nicotinamide: Altering the NAD+ cosubstrate specificity of a Sir2 enzyme. Mol. Cell 2005, 17, 855-868.

(55) Ai, T.; Wilson, D. J.; More, S. S.; Xie, J.; Chen, L. 5-((3Amidobenzyl)oxy)nicotinamides as sirtuin 2 inhibitors. J. Med. Chem. 2016, 59, 2928-2941.

(56) Cui, H.; Kamal, Z.; Ai, T.; Xu, Y.; More, S. S.; Wilson, D. J.; Chen, L. Discovery of potent and selective sirtuin 2 (SIRT2) inhibitors using a fragment-based approach. J. Med. Chem. 2014, 57, 8340-8357.

(57) Grozinger, C. M.; Chao, E. D.; Blackwell, H. E.; Moazed, D.; Schreiber, S. L. Identification of a class of small molecule inhibitors of the sirtuin family of NAD-dependent deacetylases by phenotypic screening. J. Biol. Chem. 2001, 276, 38837-38843.

(58) Heltweg, B.; Gatbonton, T.; Schuler, A. D.; Posakony, J.; Li, H.; Goehle, S.; Kollipara, R.; Depinho, R. A.; Gu, Y.; Simon, J. A.; Bedalov, 
A. Antitumor activity of a small-molecule inhibitor of human silent information regulator 2 enzymes. Cancer Res. 2006, 66, 4368-4377.

(59) Mahajan, S. S.; Scian, M.; Sripathy, S.; Posakony, J.; Lao, U.; Loe, T. K.; Leko, V.; Thalhofer, A.; Schuler, A. D.; Bedalov, A.; Simon, J. A. Development of pyrazolone and isoxazol-5-one cambinol analogues as sirtuin inhibitors. J. Med. Chem. 2014, 57, 3283-3294.

(60) Sakai, T.; Matsumoto, Y.; Ishikawa, M.; Sugita, K.; Hashimoto, Y.; Wakai, N.; Kitao, A.; Morishita, E.; Toyoshima, C.; Hayashi, T.; Akiyama, T. Design, synthesis and structure-activity relationship studies of novel sirtuin 2 (SIRT2) inhibitors with a benzamide skeleton. Bioorg. Med. Chem. 2015, 23, 328-339.

(61) Khanfar, M. A.; Quinti, L.; Wang, H.; Nobles, J.; Kazantsev, A. G.; Silverman, R. B. Design and evaluation of 3-(benzylthio)benzamide derivatives as potent and selective SIRT2 inhibitors. ACS Med. Chem. Lett. 2015, 6, 607-611.

(62) Outeiro, T. F.; Kontopoulos, E.; Altmann, S. M.; Kufareva, I.; Strathearn, K. E.; Amore, A. M.; Volk, C. B.; Maxwell, M. M.; Rochet, J. C.; McLean, P. J.; Young, A. B.; Abagyan, R.; Feany, M. B.; Hyman, B. T.; Kazantsev, A. G. Sirtuin 2 inhibitors rescue alpha-synucleinmediated toxicity in models of Parkinson's disease. Science 2007, 317, $516-519$.

(63) Fridén-Saxin, M.; Seifert, T.; Landergren, M. R.; Suuronen, T.; Lahtela-Kakkonen, M.; Jarho, E. M.; Luthman, K. Synthesis and evaluation of substituted chroman-4-one and chromone derivatives as sirtuin 2-selective inhibitors. J. Med. Chem. 2012, 55, 7104-7113.

(64) Seifert, T.; Malo, M.; Kokkola, T.; Engen, K.; Fridén-Saxin, M.; Wallén, E. A. A.; Lahtela-Kakkonen, M.; Jarho, E. M.; Luthman, K. Chroman-4-one- and chromone-based sirtuin 2 inhibitors with antiproliferative properties in cancer cells. J. Med. Chem. 2014, 57, 9870-9888.

(65) Seifert, T.; Malo, M.; Lengqvist, J.; Sihlbom, C.; Jarho, E. M.; Luthman, K. Identification of the binding site of chroman-4-one-based sirtuin 2-selective inhibitors using photoaffinity labeling in combination with tandem mass spectrometry. J. Med. Chem. 2016, 59, 1079410799.

(66) Therrien, E.; Larouche, G.; Nguyen, N.; Rahil, J.; Lemieux, A. M.; Li, Z.; Fournel, M.; Yan, T. P.; Landry, A. J.; Lefebvre, S.; Wang, J. J.; MacBeth, K.; Heise, C.; Nguyen, A.; Besterman, J. M.; Deziel, R.; Wahhab, A. Discovery of bicyclic pyrazoles as class III histone deacetylase SIRT1 and SIRT2 inhibitors. Bioorg. Med. Chem. Lett. 2015, 25, 2514-2518.

(67) Huang, Y.; Liu, J.; Yan, L.; Zheng, W. Simple N(epsilon)thioacetyl-lysine-containing cyclic peptides exhibiting highly potent sirtuin inhibition. Bioorg. Med. Chem. Lett. 2016, 26, 1612-1617.

(68) Jamonnak, N.; Hirsch, B. M.; Pang, Y.; Zheng, W. Substrate specificity of SIRT1-catalyzed lysine Nepsilon-deacetylation reaction probed with the side chain modified Nepsilon-acetyl-lysine analogs. Bioorg. Chem. 2010, 38, 17-25.

(69) Suzuki, T.; Asaba, T.; Imai, E.; Tsumoto, H.; Nakagawa, H.; Miyata, N. Identification of a cell-active non-peptide sirtuin inhibitor containing N-thioacetyl lysine. Bioorg. Med. Chem. Lett. 2009, 19, $5670-5672$.

(70) Chakrabarty, S. P.; Ramapanicker, R.; Mishra, R.; Chandrasekaran, S.; Balaram, H. Development and characterization of lysine based tripeptide analogues as inhibitors of Sir2 activity. Bioorg. Med. Chem. 2009, 17, 8060-8072.

(71) Hawse, W. F.; Hoff, K. G.; Fatkins, D. G.; Daines, A.; Zubkova, O. V.; Schramm, V. L.; Zheng, W.; Wolberger, C. Structural insights into intermediate steps in the Sir2 deacetylation reaction. Structure 2008, 16, 1368-1377.

(72) Smith, B. C.; Denu, J. M. Acetyl-lysine analog peptides as mechanistic probes of protein deacetylases. J. Biol. Chem. 2007, 282, 37256-37265.

(73) Mellini, P.; Kokkola, T.; Suuronen, T.; Salo, H. S.; Tolvanen, L.; Mai, A.; Lahtela-Kakkonen, M.; Jarho, E. M. Screen of pseudopeptidic inhibitors of human sirtuins 1-3: two lead compounds with antiproliferative effects in cancer cells. J. Med. Chem. 2013, 56, $6681-6695$
(74) Huhtiniemi, T.; Salo, H. S.; Suuronen, T.; Poso, A.; Salminen, A.; Leppanen, J.; Jarho, E.; Lahtela-Kakkonen, M. Structure-based design of pseudopeptidic inhibitors for SIRT1 and SIRT2. J. Med. Chem. 2011, 54, 6456-6468.

(75) Kiviranta, P. H.; Suuronen, T.; Wallen, E. A.; Leppanen, J.; Tervonen, J.; Kyrylenko, S.; Salminen, A.; Poso, A.; Jarho, E. M. $\mathrm{N}$ (epsilon)-thioacetyl-lysine-containing tri-, tetra-, and pentapeptides as SIRT1 and SIRT2 inhibitors. J. Med. Chem. 2009, 52, 2153-2156.

(76) Schutkowski, M.; Fischer, F.; Roessler, C.; Steegborn, C. New assays and approaches for discovery and design of Sirtuin modulators. Expert Opin. Drug Discovery 2014, 9, 183-199.

(77) Rumpf, T.; Schiedel, M.; Karaman, B.; Roessler, C.; North, B. J.; Lehotzky, A.; Olah, J.; Ladwein, K. I.; Schmidtkunz, K.; Gajer, M.; Pannek, M.; Steegborn, C.; Sinclair, D. A.; Gerhardt, S.; Ovadi, J.; Schutkowski, M.; Sippl, W.; Einsle, O.; Jung, M. Selective Sirt2 inhibition by ligand-induced rearrangement of the active site. Nat. Commun. 2015, 6, 6263.

(78) Schiedel, M.; Rumpf, T.; Karaman, B.; Lehotzky, A.; Gerhardt, S.; Ovádi, J.; Sippl, W.; Einsle, O.; Jung, M. Structure-based development of an affinity probe for sirtuin 2. Angew. Chem., Int. Ed. 2016, 55, 2252-2256.

(79) Schiedel, M.; Rumpf, T.; Karaman, B.; Lehotzky, A.; Olah, J.; Gerhardt, S.; Ovadi, J.; Sippl, W.; Einsle, O.; Jung, M. Aminothiazoles as potent and selective sirt2 inhibitors: A structure-activity relationship study. J. Med. Chem. 2016, 59, 1599-1612.

(80) Weiser, B. P.; Eckenhoff, R. G. Propofol inhibits SIRT2 deacetylase through a conformation-specific, allosteric site. J. Biol. Chem. 2015, 290, 8559-8568.

(81) Di Fruscia, P.; Zacharioudakis, E.; Liu, C.; Moniot, S.; Laohasinnarong, S.; Khongkow, M.; Harrison, I. F.; Koltsida, K.; Reynolds, C. R.; Schmidtkunz, K.; Jung, M.; Chapman, K. L.; Steegborn, C.; Dexter, D. T.; Sternberg, M. J.; Lam, E. W.; Fuchter, M. $\mathrm{J}$. The discovery of a highly selective 5,6,7,8-tetrahydrobenzo[4,5]thieno[2,3-d]pyrimidin-4(3H)-one SIRT2 inhibitor that is neuroprotective in an in vitro Parkinson's disease model. ChemMedChem 2015, 10, 69-82.

(82) Di Fruscia, P.; Ho, K. K.; Laohasinnarong, S.; Khongkow, M.; Kroll, S. H.; Islam, S. A.; Sternberg, M. J.; Schmidtkunz, K.; Jung, M.; Lam, E. W.; Fuchter, M. J. The discovery of novel 10,11-dihydro-5Hdibenz[b,f]azepine SIRT2 inhibitors. MedChem Comm 2012, 3, 373378.

(83) Trapp, J.; Meier, R.; Hongwiset, D.; Kassack, M. U.; Sippl, W.; Jung, M. Structure-activity studies on suramin analogues as inhibitors of NAD+-dependent histone deacetylases (sirtuins). ChemMedChem 2007, 2, 1419-1431.

(84) Parenti, M. D.; Bruzzone, S.; Nencioni, A.; Del Rio, A. Selectivity hot-spots of sirtuin catalytic cores. Mol. BioSyst. 2015, 11, 2263-2272.

(85) Li, Y.; Han, L.; Liu, Z.; Wang, R. Comparative assessment of scoring functions on an updated benchmark: 2. Evaluation methods and general results. J. Chem. Inf. Model. 2014, 54, 1717-1736.

(86) Ross, G. A.; Morris, G. M.; Biggin, P. C. One size does not fit all: The limits of structure-based models in drug discovery. J. Chem. Theory Comput. 2013, 9, 4266-4274.

(87) Smith, R. D.; Dunbar, J. B.; Ung, P. M.-U.; Esposito, E. X.; Yang C.-Y.; Wang, S.; Carlson, H. A. CSAR benchmark exercise of 2010: Combined evaluation across all submitted scoring functions. J. Chem. Inf. Model. 2011, 51, 2115-2131.

(88) Wang, R.; Lu, Y.; Fang, X.; Wang, S. An extensive test of 14 scoring functions using the PDBbind refined set of 800 protein-ligand complexes. J. Chem. Inf. Comput. Sci. 2004, 44, 2114-2125.

(89) North, B. J.; Marshall, B. L.; Borra, M. T.; Denu, J. M.; Verdin, E. The human Sir2 ortholog, SIRT2, is an NAD+-dependent tubulin deacetylase. Mol. Cell 2003, 11, 437-444.

(90) Yoshida, M.; Kijima, M.; Akita, M.; Beppu, T. Potent and specific inhibition of mammalian histone deacetylase both in vivo and in vitro by trichostatin A. J. Biol. Chem. 1990, 265, 17174-17179.

(91) Gong, C.; Yao, S.; Gomes, A. R.; Man, E. P.; Lee, H. J.; Gong, G.; Chang, S.; Kim, S. B.; Fujino, K.; Kim, S. W.; Park, S. K.; Lee, J. 
W.; Lee, M. H.; Khoo, U. S.; Lam, E. W. BRCA1 positively regulates FOXO3 expression by restricting $\mathrm{FOXO} 3$ gene methylation and epigenetic silencing through targeting EZH2 in breast cancer. Oncogenesis 2016, 5, e214.

(92) Khongkow, M.; Olmos, Y.; Gong, C.; Gomes, A. R.; Monteiro, L. J.; Yague, E.; Cavaco, T. B.; Khongkow, P.; Man, E. P.; Laohasinnarong, S.; Koo, C. Y.; Harada-Shoji, N.; Tsang, J. W.; Coombes, R. C.; Schwer, B.; Khoo, U. S.; Lam, E. W. SIRT6 modulates paclitaxel and epirubicin resistance and survival in breast cancer. Carcinogenesis 2013, 34, 1476-1486.

(93) Wiedman, G.; Fuselier, T.; He, J.; Searson, P. C.; Hristova, K.; Wimley, W. C. Highly efficient macromolecule-sized poration of lipid bilayers by a synthetically evolved peptide. J. Am. Chem. Soc. 2014, 136, 4724.

(94) Jacobson, M. P.; Friesner, R. A.; Xiang, Z.; Honig, B. On the role of the crystal environment in determining protein side-chain conformations. J. Mol. Biol. 2002, 320, 597-608.

(95) Jacobson, M. P.; Pincus, D. L.; Rapp, C. S.; Day, T. J. F.; Honig, B.; Shaw, D. E.; Friesner, R. A. A hierarchical approach to all-atom protein loop prediction. Proteins: Struct., Funct., Genet. 2004, 55, 351-367.

(96) Banks, J. L.; Beard, H. S.; Cao, Y.; Cho, A. E.; Damm, W.; Farid, R.; Felts, A. K.; Halgren, T. A.; Mainz, D. T.; Maple, J. R.; Murphy, R.; Philipp, D. M.; Repasky, M. P.; Zhang, L. Y.; Berne, B. J.; Friesner, R. A.; Gallicchio, E.; Levy, R. M. Integrated modeling program, applied chemical theory (IMPACT). J. Comput. Chem. 2005, 26, 1752-1780.

(97) Greenwood, J.; Calkins, D.; Sullivan, A.; Shelley, J. Towards the comprehensive, rapid, and accurate prediction of the favorable tautomeric states of drug-like molecules in aqueous solution. J. Comput.-Aided Mol. Des. 2010, 24, 591-604.

(98) Shelley, J.; Cholleti, A.; Frye, L.; Greenwood, J.; Timlin, M.; Uchimaya, M. Epik: a software program for $\mathrm{pK}$ a prediction and protonation state generation for drug-like molecules. J. Comput.-Aided Mol. Des. 2007, 21, 681-691.

(99) Friesner, R. A.; Banks, J. L.; Murphy, R. B.; Halgren, T. A.; Klicic, J. J.; Mainz, D. T.; Repasky, M. P.; Knoll, E. H.; Shelley, M.; Perry, J. K.; Shaw, D. E.; Francis, P.; Shenkin, P. S. Glide: A new approach for rapid, accurate docking and scoring. 1. Method and assessment of docking accuracy. J. Med. Chem. 2004, 47, 1739-1749.

(100) Friesner, R. A.; Murphy, R. B.; Repasky, M. P.; Frye, L. L.; Greenwood, J. R.; Halgren, T. A.; Sanschagrin, P. C.; Mainz, D. T. Extra precision glide: docking and scoring incorporating a model of hydrophobic enclosure for protein-ligand complexes. J. Med. Chem. 2006, 49, 6177-6196.

(101) Halgren, T. A.; Murphy, R. B.; Friesner, R. A.; Beard, H. S.; Frye, L. L.; Pollard, W. T.; Banks, J. L. Glide: A new approach for rapid, accurate docking and scoring. 2. Enrichment factors in database screening. J. Med. Chem. 2004, 47, 1750-1759.

(102) Sander, T.; Freyss, J.; von Korff, M.; Rufener, C. DataWarrior: An open-source program for chemistry aware data visualization and analysis. J. Chem. Inf. Model. 2015, 55, 460-473.

(103) Mueller, U.; Förster, R.; Hellmig, M.; Huschmann, F. U.; Kastner, A.; Malecki, P.; Pühringer, S.; Röwer, M.; Sparta, K.; Steffien, M.; Ühlein, M.; Wilk, P.; Weiss, M. S. The macromolecular crystallography beamlines at BESSY II of the Helmholtz-Zentrum Berlin: Current status and perspectives. Eur. Phys. J. Plus 2015, 130, 141.

(104) Sparta, K. M.; Krug, M.; Heinemann, U.; Mueller, U.; Weiss, M. S. XDSAPP2.0. J. Appl. Crystallogr. 2016, 49, 1085-1092.

(105) Vagin, A.; Teplyakov, A. MOLREP: an automated program for molecular replacement. J. Appl. Crystallogr. 1997, 30, 1022-1025.

(106) Afonine, P. V.; Grosse-Kunstleve, R. W.; Echols, N.; Headd, J. J.; Moriarty, N. W.; Mustyakimov, M.; Terwilliger, T. C.; Urzhumtsev, A.; Zwart, P. H.; Adams, P. D. Towards automated crystallographic structure refinement with phenix.refine. Acta Crystallogr., Sect. D: Biol. Crystallogr. 2012, 68, 352-367.

(107) Emsley, P.; Lohkamp, B.; Scott, W. G.; Cowtan, K. Features and development of Coot. Acta Crystallogr., Sect. D: Biol. Crystallogr. 2010, 66, 486-501.
(108) Baker, N. A.; Sept, D.; Joseph, S.; Holst, M. J.; McCammon, J. A. Electrostatics of nanosystems: application to microtubules and the ribosome. Proc. Natl. Acad. Sci. U. S. A. 2001, 98, 10037-10041.

(109) Diederichs, K.; Karplus, P. A. Improved R-factors for diffraction data analysis in macromolecular crystallography. Nat. Struct. Biol. 1997, 4, 269-275.

(110) Karplus, P. A.; Diederichs, K. Linking crystallographic model and data quality. Science 2012, 336, 1030-1033. 